INTER NATIONAL MONETARY FUND

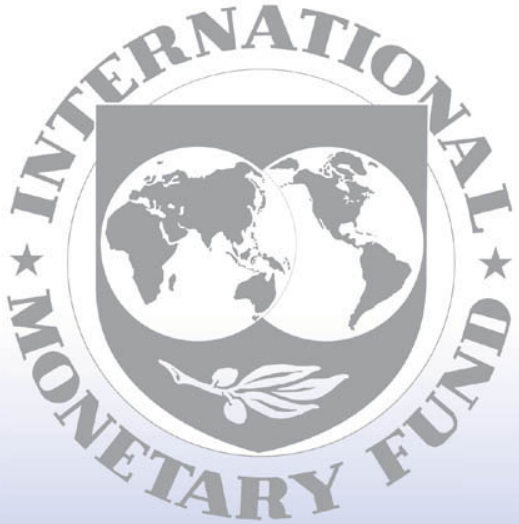

Staff

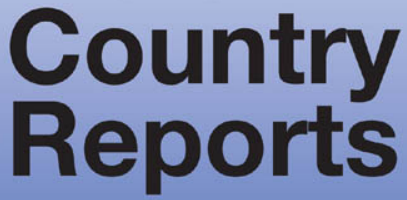




\title{
Papua New Guinea: 2008 Article IV Consultation-Staff Report; Public Information Notice on the Executive Board Discussion; and Statement by the Executive Director for Papua New Guinea
}

Under Article IV of the IMF's Articles of Agreement, the IMF holds bilateral discussions with members, usually every year. In the context of the Article IV consultation with Papua New Guinea, the following documents have been released and are included in this package:

- $\quad$ The staff report for the 2008 Article IV consultation, prepared by a staff team of the IMF, following discussions that ended on December 15, 2008, with the officials of Papua New Guinea on economic developments and policies. Based on information available at the time of these discussions, the staff report was completed on February 27, 2009. The views expressed in the staff report are those of the staff team and do not necessarily reflect the views of the Executive Board of the IMF.

- $\quad$ A Public Information Notice (PIN) summarizing the views of the Executive Board as expressed during its March 16, 2009 discussion of the staff report that concluded the Article IV consultation.

- $\quad$ A statement by the Executive Director for Papua New Guinea.

The document listed below has been or will be separately released.

Selected Issues and Statistical Appendix Paper

The policy of publication of staff reports and other documents allows for the deletion of market-sensitive information.

\author{
Copies of this report are available to the public from \\ International Monetary Fund • Publication Services \\ $70019^{\text {th }}$ Street, N.W. • Washington, D.C. 20431 \\ Telephone: (202) 623-7430 • Telefax: (202) 623-7201 \\ E-mail: publications@imf.org Internet: http://www.imf.org
}

\section{International Monetary Fund \\ Washington, D.C.}


This page intentionally left blank 
INTERNATIONAL MONETARY FUND

PAPUA NEW GUINEA

\title{
Staff Report for the 2008 Article IV Consultation
}

\author{
Prepared by the Asia and Pacific Department \\ (In consultation with other departments)
}

Approved by James Gordon and Anthony Boote

February 27, 2009

Discussions: Port Moresby, December 4-15 with the Governor of the Bank of Papua New Guinea L. Wilson Kamit, the Acting Deputy Secretary of the Department of Treasury Anthony Yauieb, and other senior officials and representatives of the private sector.

Team: Mr. Hunt (Head), Ms. Tumbarello, Messrs. Erdembileg, and J. S. Kang (all APD). Mr. Legg (OED) participated in the discussions.

Mission focus: Coping with declining commodity prices; managing the accumulated mineral wealth; and strengthening the private nonmineral sector.

Past Surveillance: For policy issues discussed in the 2007 Article IV Consultation, see http://www.imf.org/external/pubs/cat/longres.cfm?sk=21794.0

Economic statistics: Data provision has some shortcomings, but is broadly adequate for surveillance.

Exchange rate regime: Floating. Papua New Guinea is an Article VIII country and maintains an exchange system free of restrictions on payments and transfers for current international transactions.

Political Developments: Following national elections in July 2007, parliament elected Sir Michael Somare for another term as Prime Minister. Political stability has increased in PNG. New governments now enjoy an 18-month grace period before no-confidence motions can be brought to parliament and elected members must immediately stand for re-election if they choose to change their party affiliation.

Word count: 4,992 
Executive Summary

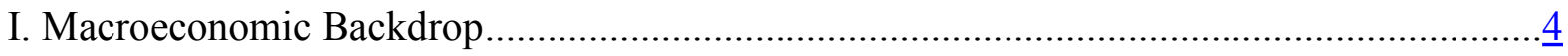

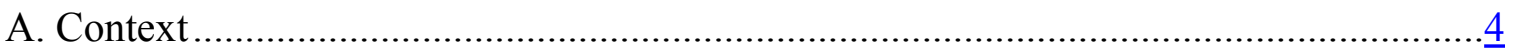

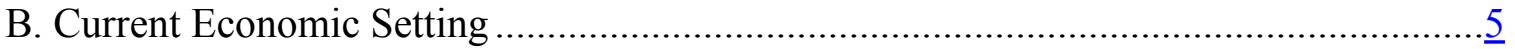

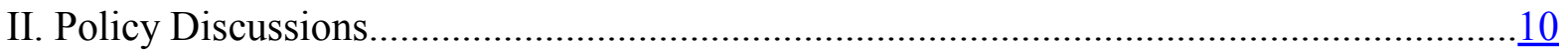

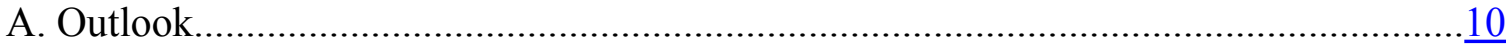

B. Fiscal Policy_-Managing the Mineral Wealth.........................................................11

C. Monetary Policy — Guarding Against Persistently High Inflation .............................14

D. Financial Sector - Coping with the Financial Turmoil .........................................15

E. Assessing the Equilibrium Real Exchange Rate and External Stability.......................16

F. Fostering Sustainable, Broad-Based Growth.............................................................18

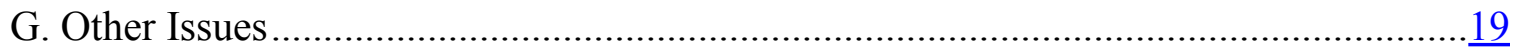

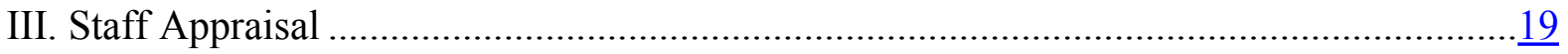

Boxes

1. The Global Financial Turmoil: The Impact on Papua New Guinea …..............................

2. The New Medium-Term Fiscal Strategy ...................................................................11

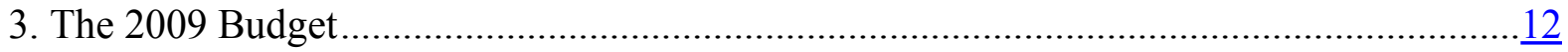

4. GDP Impact of the LNG Project.........................................................

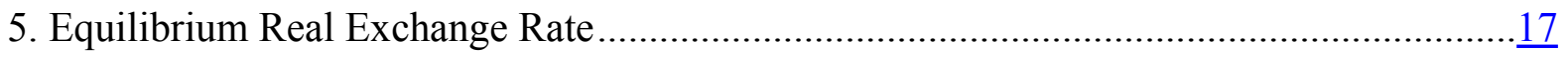

Figures

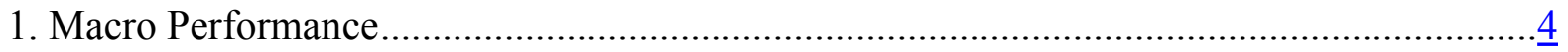

2. Prolonged Expansion Driven by Favorable Terms of Trade ........................................... $\underline{5}$

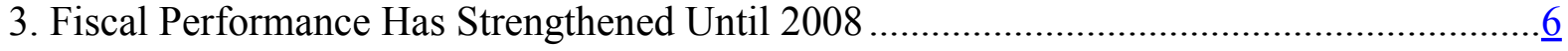

4. The Monetary Stance Remains Accommodative............................................................. 1

5. The External Position Has Strengthened ................................................................ $\underline{9}$

Tables

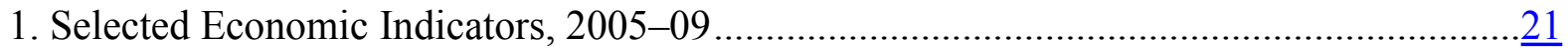

2. Balance of Payments, 2007-13 ...............................................................................

3. Medium-Term Scenario, 2007-13 .....................................................................

4. Summary Accounts of the Banking System, 2005-09 ….............................................24

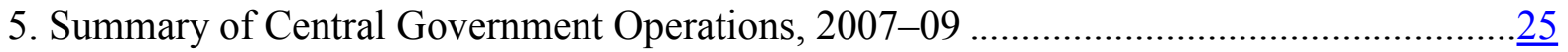

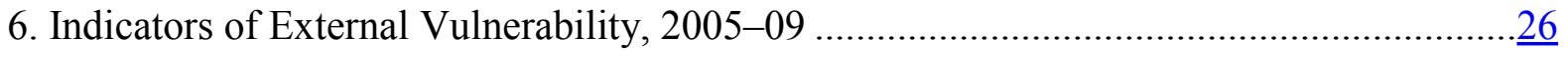

7. Millennium Development Goals Progress, 1990-2007 ...................................................27

8. Authorities' Response to Recent Fund Policy Advice...................................................28

Appendices

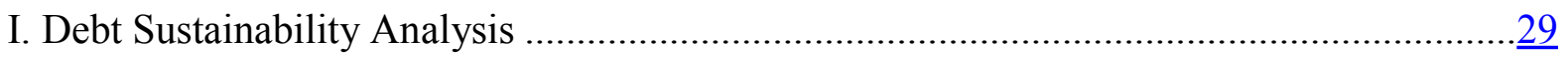




\section{EXECUTIVE SUMMARY}

Background: Papua New Guinea is feeling the impact of the global crisis primarily through collapsing commodity prices. Growth is expected to slow in 2009, and the outlook remains uncertain. Nevertheless, the positive sentiment associated with the prospective Liquefied Natural Gas (LNG) project is spurring domestic demand. Moreover, a sound fiscal position and a relatively insulated financial sector mean that the economy is better placed than many to weather the storm.

Main issues: The main challenge is to cope with a rapidly deteriorating external environment while ensuring that the accumulated mineral windfall is used effectively to support sustainable growth.

Staff views: Given the external environment, staff endorse some fiscal loosening in 2009, but are concerned about the magnitude and the quality of public spending. The current monetary stance is appropriate. However, staff called for policy to react quickly to shifts in the balance of risks to inflation and growth. The kina appears mildly overvalued and should be allowed to adjust to help offset the impact of declining commodity prices on export incomes.

Authorities' views: There was broad agreement on most issues and the required policy responses. The authorities stressed that monetary policy needed to remain focused on price stability given the current outlook. Although they saw merit in allowing the exchange rate to adjust, they noted that smoothing exchange rate movements was key to anchoring inflation expectations. On the fiscal front, the authorities were mindful about the importance of maintaining medium-term fiscal sustainability, but pointed to the mounting pressures to spend some of the accumulated mineral windfall given the country's development needs. 


\section{MACROECONOMIC BACKDROP}

\section{A. Context}

1. Macroeconomic performance has improved, but Papua New Guinea remains a poor country highly exposed to commodity price fluctuations. Buoyed by commodity export revenues, GDP growth performance has improved notably in the last several years. Until recently, inflation has remained low, thanks to favorable terms-of-trade and improved macroeconomic management. However, GDP per capita remains low and improvements in living standards have lagged other low-income countries in the region. An unattractive investment environment, due primarily to weak infrastructure, problems with governance, and high crime, constrains more rapid growth of the nonmineral sector. The economy remains highly vulnerable to swings in commodity prices owing to their importance in both export and public revenue.

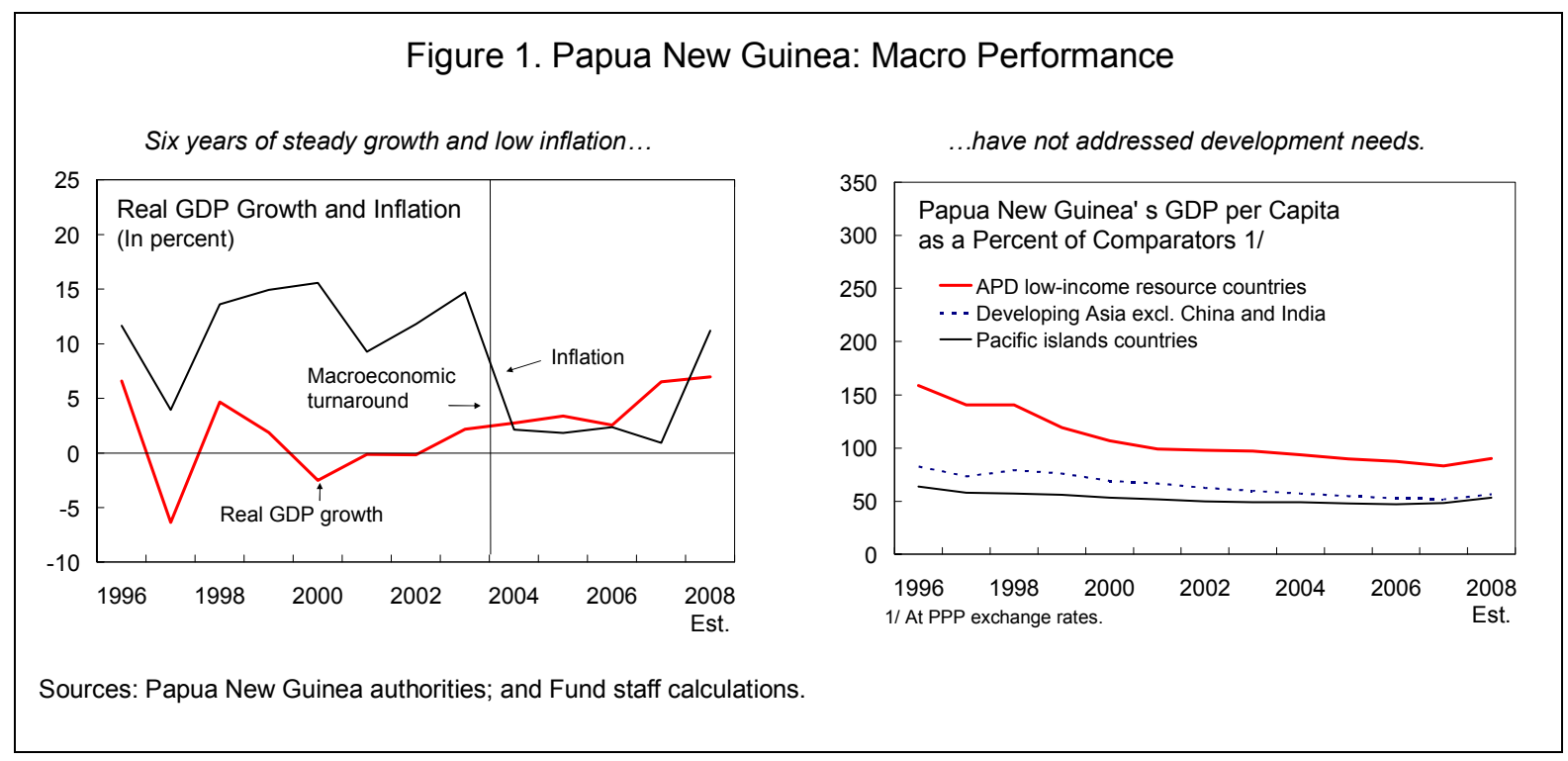




\section{B. Current Economic Setting}

2. Papua New Guinea experienced high growth and a pick-up in inflation in 2008. Real GDP grew by 6.5 percent in 2007, on the back of strong growth in the nonmineral sector (7.3 percent), especially in construction and communications. Leading indicators, including employment rates and retail sales, suggest that activity continued to expand rapidly in 2008. After remaining in the low single digits during 2004-07, CPI inflation accelerated in late-2007, reaching nearly 13.5 percent (y/y) in September 2008. Although this mainly reflects rising food and energy prices, there are some limited indicators of broad-based inflation pressures.

Figure 2. Papua New Guinea: Prolonged Expansion Driven by Favorable Terms of Trade
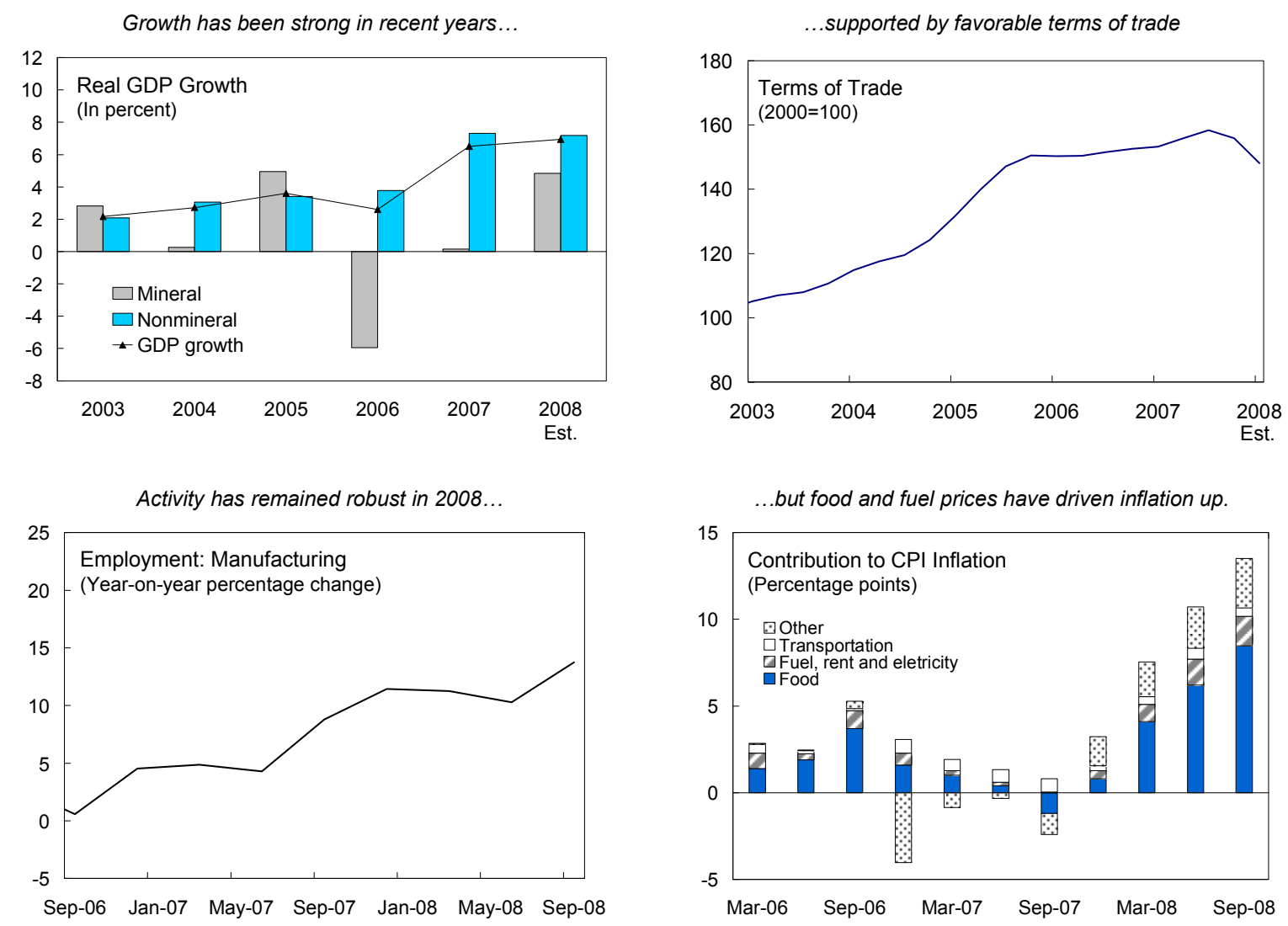

Sources: Bank of Papua New Guinea; and Fund staff calculations. 
3. The fiscal position had strengthened until recently. In the last few years, the fiscal balance has consistently overperformed, with the mineral windfall largely saved and public debt reduced. However, reliance on mineral revenue has increased and the nonmineral deficit has remained high. For 2008, the estimated fiscal surplus is 4.5 percent of GDP, down from 8 percent in 2007. The projected narrowing of the fiscal surplus in 2008 reflected a large drop in mineral revenues, which more than offset lower-than-expected development expenditure. The 2009 budget balance envisages a reversal, turning from surplus into deficit given the expected drop in mineral revenues and higher planned expenditure.

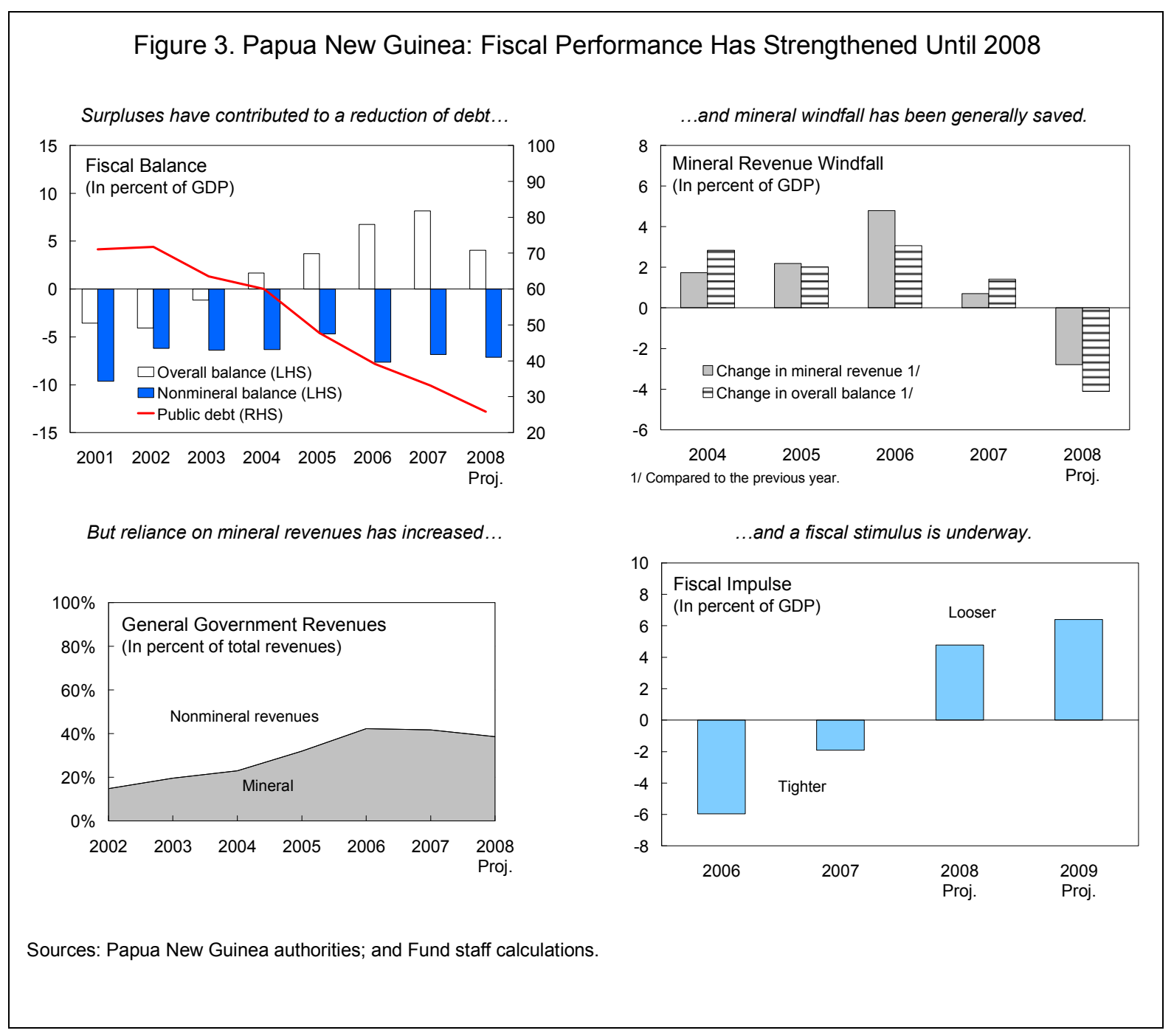


4. The policy interest rate was increased during the second half of the year, but monetary conditions remain accommodative. Since June 2008 , the policy rate was increased four times by a total of 200 basis points, to its current rate of 8 percent. However, high inflation has reduced real lending rates. Despite some sterilization, the large increase in foreign reserves through August contributed to an easing in credit conditions. Credit growth accelerated to 41 percent (y/y) in December 2008 from 34 percent (y/y) at end-2007.

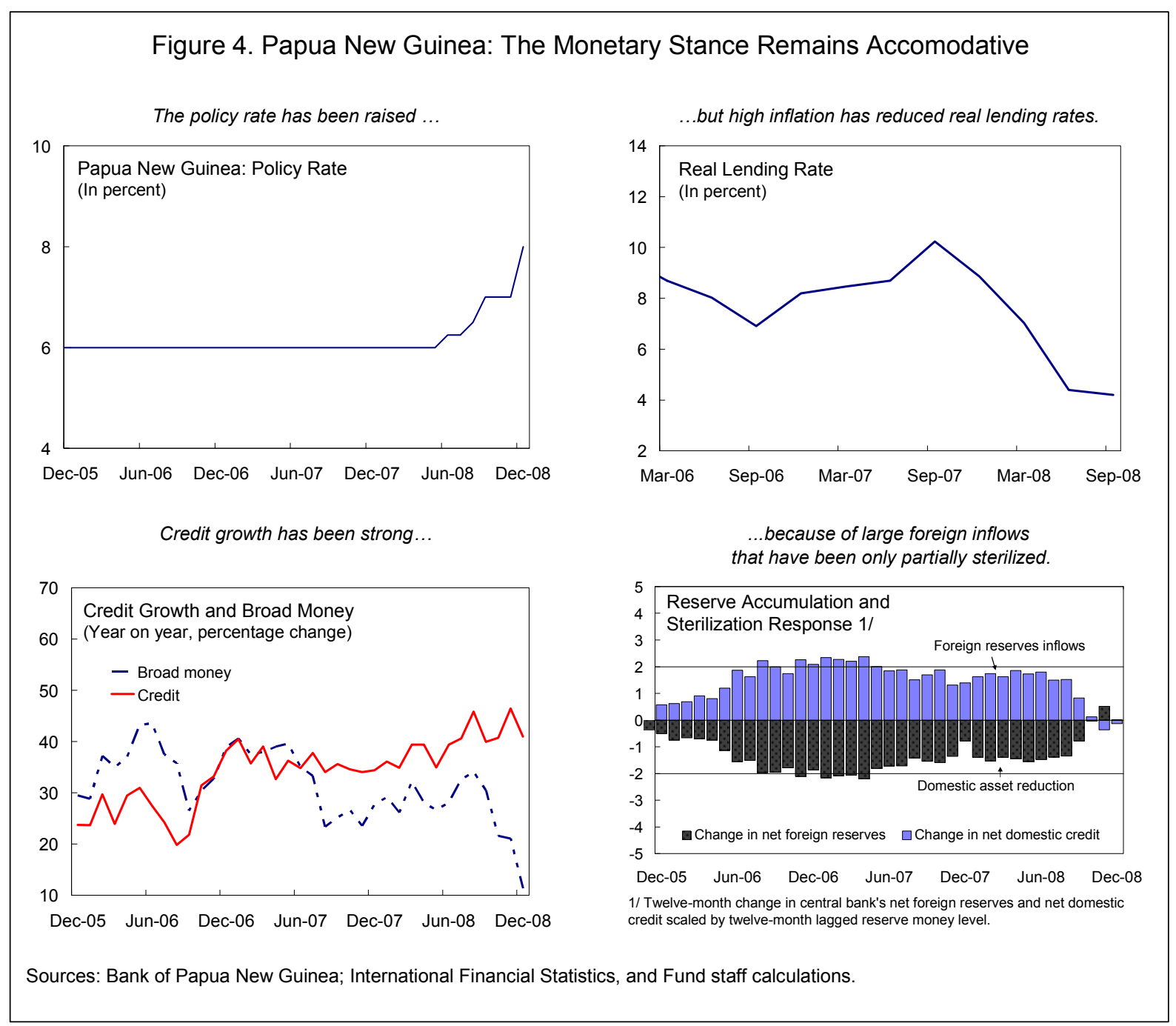

5. To date, spillovers from the global financial market turmoil have been limited. Banks are very liquid and largely isolated from international capital markets (Box 1). The stock market has weakened since June, in line with other stock markets in the region. 


\section{Box 1. The Global Financial Turmoil: The Impact on Papua New Guinea ${ }^{1}$}

The exposure of Papua New Guinea's financial sector to global financial markets is minimal and spillovers from the current turmoil have so far been limited. Total financial sector assets represent roughly 85 percent of GDP, with commercial banks dominating the sector. Three large banks hold about 70 percent of total financial sector assets. The nationally owned Bank of South Pacific is the largest, holding 50 percent of bank assets.
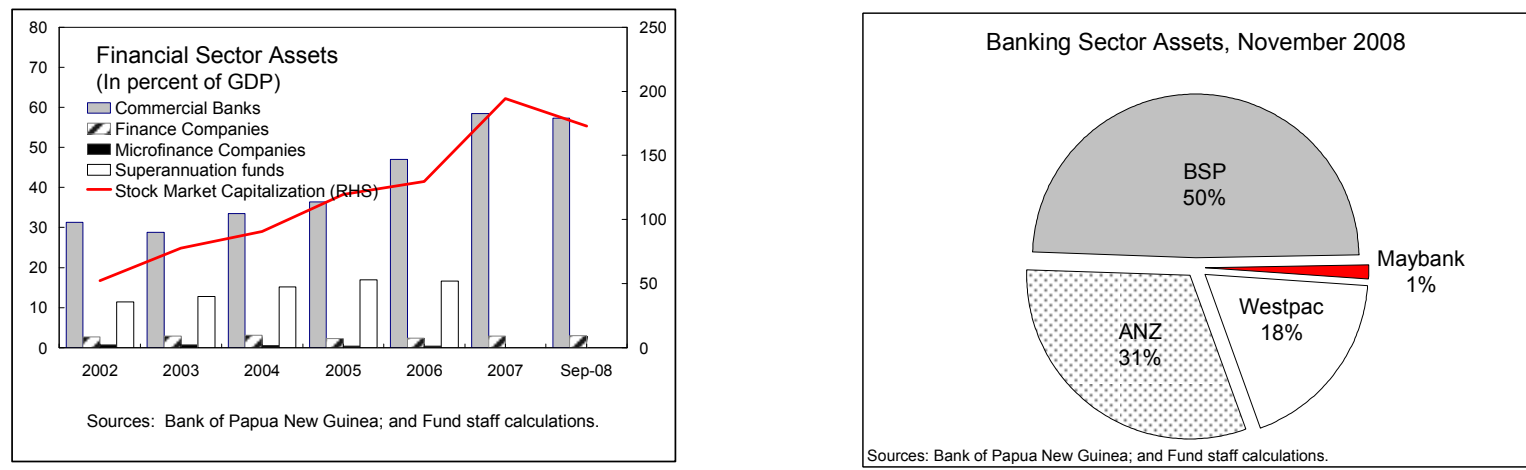

Banks are not vulnerable to international credit markets developments as their balance sheets are funded primarily by domestic currency deposits and are highly liquid. Deposits comprise approximately 80 percent of bank liabilities, with foreign currency deposits representing about 10 percent. About 60 percent of total banking sector assets are liquid. Lending, which represent 35 percent of bank assets, is directed primarily to the business sector. While only 1.3 percent of loans are currently classified as non-performing, banks maintain high provisioning against default.
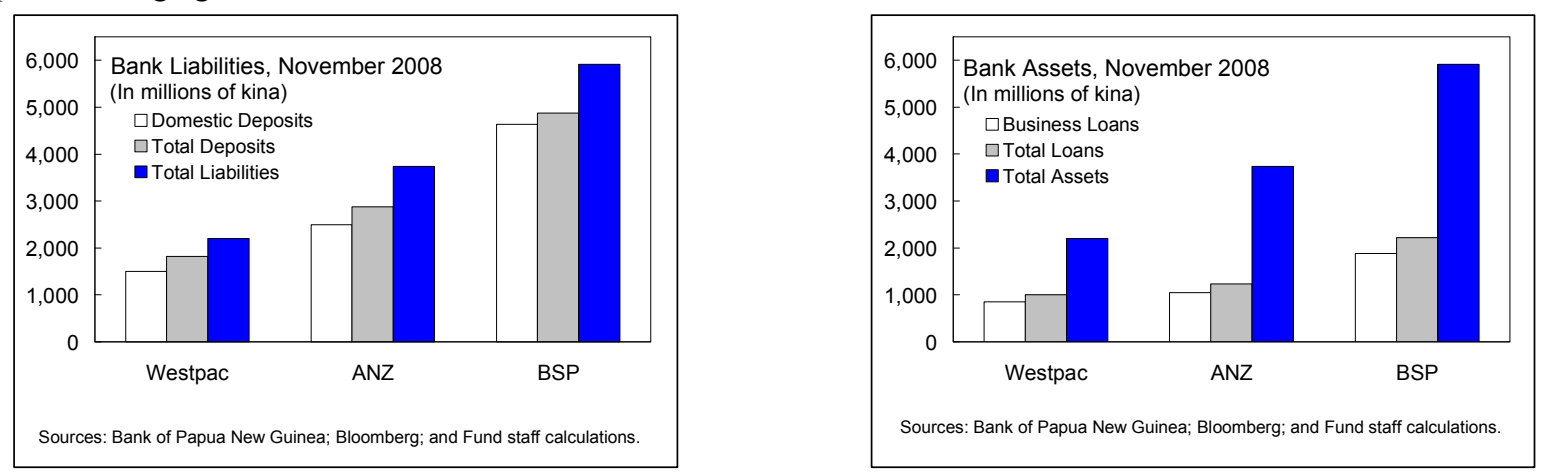

The foreign currency deposits most vulnerable to withdrawal from Papua New Guinea amount to 5 percent of bank assets and are held by the two Australian subsidiaries. Although no guarantee is provided on these deposits, by either the domestic or Australian authorities, there has been no shift of these deposits toward the parent banks that now enjoy a full deposit guarantee in Australia.

\section{Spillovers from international markets have been observed} in the equity market. As of end-2008, the Kina Securities Index was about 40 percent below its peak in June, a similar decline witnessed in most other equity markets around the world.

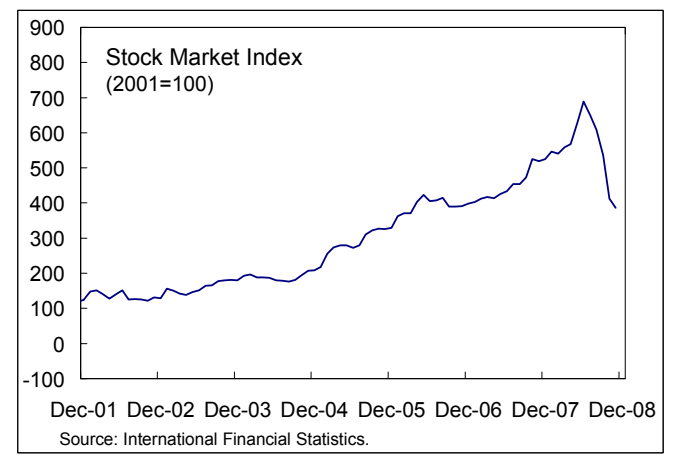

${ }^{1}$ Selected Issues Paper "The Global Financial Turmoil: The Impact on Papua New Guinea's Financial Sector." 


\section{Until recently, effective exchange rates have remained stable, but commodity} price vulnerability lingers. Both the real and nominal effective exchange rates have been stable since 2003 through mid-August 2008, while improved terms-of-trade delivered a sequence of current account surpluses. Preliminary data up to the third quarter of 2008 suggest that the current account surplus widened further, propelled by the global commodity boom, although this trend may have been reversed during the last quarter of the year with the decline in commodity export prices. Current account surpluses reduced external debt to about 27 percent of GDP at end-2008. Official foreign exchange reserves rose to US $\$ 2.7$ billion in early August, reflecting large commodity-price-related revenue inflows. In the second half of 2008 , reserves were drawn down to about US\$2 billion resisting depreciation pressures in the kina/U.S. dollar rate owing to falling commodity prices. Consequently, the real effective exchange rate has appreciated since August, primarily because of the depreciation in the Australian dollar against the U.S. dollar.

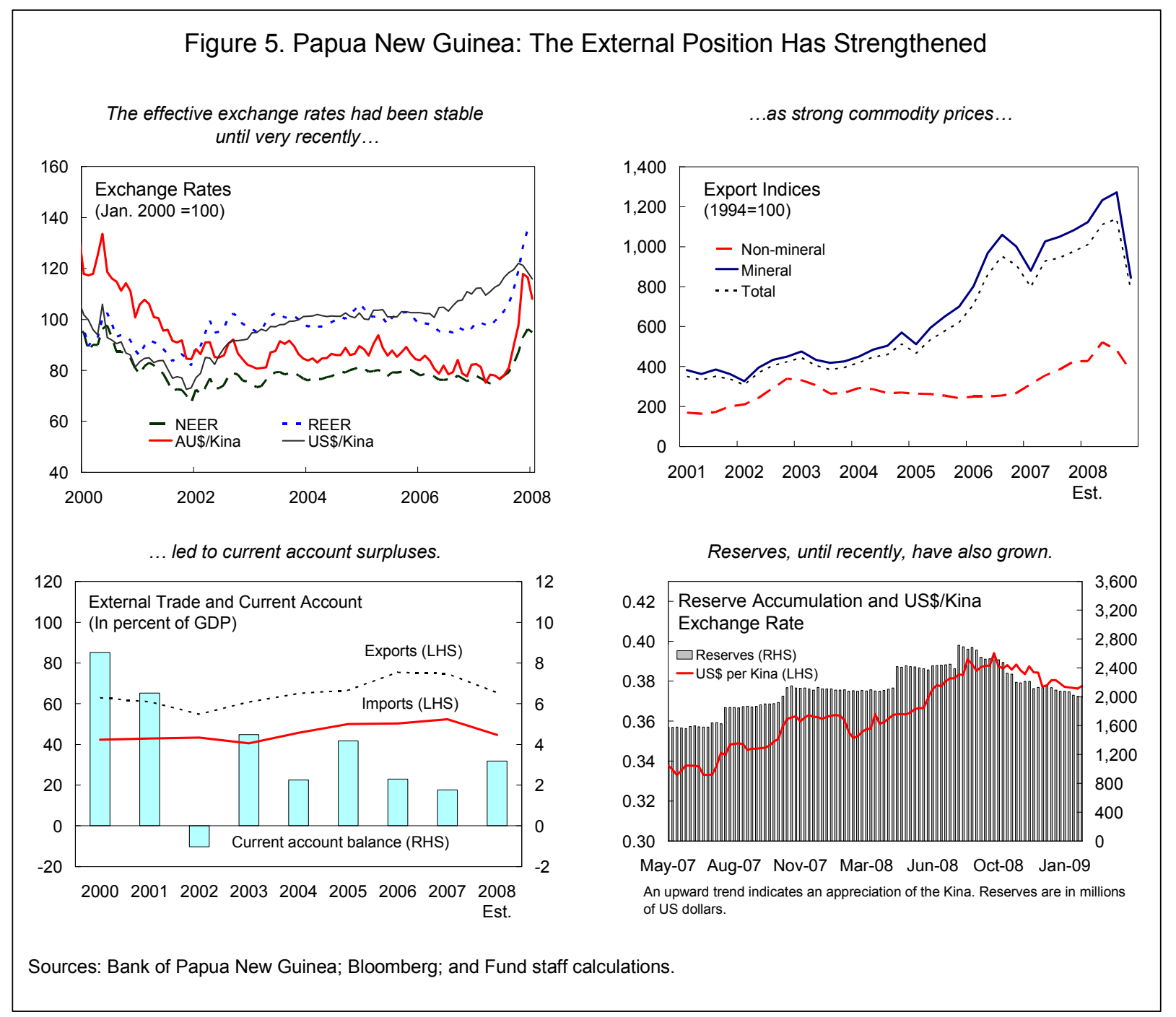




\section{Policy Discussions}

7. In the near-term, the challenge is to cope with a rapidly deteriorating external environment while ensuring that the accumulated mineral windfall is used effectively to support sustainable growth. In the medium term, the priority is to strengthen the private nonmineral sector to help close the development gap with regional peers and reduce external vulnerability. Accordingly, discussions focused on:

- managing the accumulated fiscal surpluses ensuring that the mineral windfall is directed toward achieving more broad-based growth;

- guarding against persistently high inflation; and

- $\quad$ assessing financial sector stability.

\section{A. Outlook}

8. In line with global developments, staff and the authorities agreed that activity is slowing. Staff project growth to ease to under 4 percent in 2009 from an estimated 7 percent in 2008 , with a slowdown in both the nonmineral and minerals sectors. The authorities were slightly more optimistic, expecting the positive sentiment associated with the prospective LNG project (Box 4) to stimulate the nonmineral sector through

\begin{tabular}{|lrrrrrr|}
\hline \multicolumn{5}{|c|}{ Papua New Guinea: Macroeconomic Framework, 2008-13 } \\
\hline & 2008 & 2009 & 2010 & 2011 & 2012 & 2013 \\
\hline \multicolumn{7}{c|}{ (Percentage change) } \\
Real GDP & 7.0 & 3.9 & 3.7 & 3.3 & 3.0 & 2.4 \\
$\quad$ Mineral GDP & 4.8 & 2.6 & 4.2 & 3.0 & 0.1 & -2.4 \\
Nonmineral GDP & 7.2 & 4.1 & 3.7 & 3.4 & 3.3 & 2.9 \\
CPI inflation (eop) & 11.2 & 5.3 & 4.8 & 4.5 & 4.0 & 3.5 \\
& \multicolumn{7}{c|}{ (In percent of GDP) } \\
Current account balance & 2.8 & -6.7 & -4.7 & -4.3 & -3.9 & -3.1 \\
Overall fiscal balance & 4.5 & -2.0 & -1.5 & -1.5 & -1.0 & -1.3 \\
Nonmineral fiscal balance & -6.7 & -7.2 & -6.2 & -6.0 & -5.7 & -6.0 \\
\hline Sources: Papua New Guinea authorities; and Fund staff projections. \\
\hline
\end{tabular}
higher investment. ${ }^{1}$ Staff expect inflation to ease quickly, as commodity-price declines feed through. The Bank of Papua New Guinea (BPNG) officials noted that domestic price pressures may add some persistence, despite declining food and energy prices, given the boost to confidence from the LNG project and increased public spending envisaged in the 2009 budget. $^{2}$

\footnotetext{
${ }^{1}$ Although raising the required capital for the LNG project could be difficult given conditions in global financial markets, many expect the project to start as proposed, in part because of Exxon's comments that it is one of their most attractive prospective projects.

${ }^{2}$ With a final approval for the LNG project not expected until end-2009, it is not included in the staff's baseline forecast.
} 
9. There was broad agreement that downside risks dominate, albeit with some mitigating factors. Given the risk of further deterioration in the global economy, the outlook remains highly vulnerable to additional weakening in the terms of trade and further softening in external demand. On the upside, expectations that the LNG project will move forward may have a larger-than-expected positive impact on domestic demand.

\section{B. Fiscal Policy-Managing Mineral Wealth}

10. Staff commended the authorities for adopting the Medium-Term Fiscal Strategy (MTFS) (Box 2). The framework reduces the exposure of the budget to the volatility of mineral revenues with a rule constraining the nonmineral deficit to be no more than 8 percent of GDP. The ongoing-spending nonmineral deficit cannot exceed 4 percent of GDP-the assessed structural ratio of mineral revenue to GDP. However, the strategy also allows for additional public investment of up to 4 percent of GDP from accumulated past surpluses, provided it is directed toward achieving Medium-Term Development Strategy (MTDS) goals.

\section{Box 2. The New Medium-Term Fiscal Strategy}

In July 2008, the Government approved a new MTFS for the period 2008-12. Under this strategy, the nonmineral fiscal deficit is constrained to fall within a range of 4 to 8 percent of GDP. This range has been chosen based on the following principles:

- $\quad$ Ongoing spending (including recurrent and development spending) should be kept in line with "normal revenues". Normal revenues are defined as the sum of nonmineral revenues and normal mineral revenues - the mineral revenues that would be expected without a commodity-price boom, about 4 percent of GDP. Ongoing spending is limited to the sum of normal mineral revenues and nonmineral revenues.

- $\quad$ Mineral revenues above 4 percent of GDP should be used for "one-off" expenditures, debt reduction (30 percent) and additional public investment ( 70 percent). Amounts not used for debt reduction accumulate in trust accounts to be drawn down over time. In any year, no more that 4 percent of GDP can be spent from the trust accounts on additional public investment.

The estimate of normal mineral revenues is based on the average from the pre-boom years of 1999-2003 and the expected performance in 2010-12 based on planned production and IMF commodity price forecasts. Every two years, the government will reassess the appropriateness of the 4 percent of GDP estimate of normal mineral revenues.

11. The new MTFS will significantly strengthen the fiscal framework, but staff emphasized that it would benefit from some fine tuning. The framework still contains the potential for procyclicality by allowing greater investment spending in the event of more buoyant mineral revenues. To reduce the risk of procyclicality, staff advised that the cyclical 
position of the economy be used explicitly to determine the amount of excess mineral revenue to be spent each year. The authorities saw merit in this recommendation.

\section{On the $\mathbf{2 0 0 9}$ budget, staff agreed that some fiscal loosening was appropriate} given the external environment, but expressed concerns about the magnitude (Box 3 ). Provided inflation eases as expected and spare capacity is available, cyclical conditions could accommodate increased public investment expenditure. Although the magnitude of the 2009 deficit is expected to fall within MTFS limits, the fiscal stance will be too expansionary given the cyclical position of the economy and aiming for a balanced budget on staff's definition would be more prudent. Further, given the revenue outlook, the level of public spending in the budget cannot be maintained without undermining debt sustainability.

\section{Box 3. The 2009 Budget}

The 2009 fiscal stance is expansionary. The fiscal balance is expected to deteriorate to -2 percent of GDP from an expected surplus of 4.5 percent of GDP in 2008, reflecting a large drop in mineral revenues and higher expenditure.

The budget may underestimate the increase in expenditure: ${ }^{1}$

- First, District Service Improvement Program (DSIP) expenditure may turn out to be higher. The 2009 budget allocates 356 million kina (1.8 percent of GDP) to be directed to districts and provinces and financed with accumulated surpluses held in trust accounts. This is in addition to the 890 million kina (4.2 percent of GDP) allocated in the 2007-08 budgets to the DSIP, of which only 0.2 percent of GDP had been spent as of end-September 2008. Given the recent easing of the constraints on spending from DSIP trust accounts (i.e., removal of restrictions on type and timing of expenditures), the total envelope to be spent under the DSIP could amount to 6 percent of GDP in 2009.

- Second, the budget does not factor in the increase in the minimum wage introduced in February. The total increase in the minimum wage is 170 percent. It will be phased in over 40 weeks, starting mid-February through mid-October.

\begin{tabular}{|c|c|c|c|}
\hline \multicolumn{4}{|c|}{$\begin{array}{l}\text { Summary of Central Government Operations } \\
\text { (In percent of GDP) }\end{array}$} \\
\hline & \multirow{2}{*}{$\frac{2008}{\text { Staff Proj. }}$} & \multicolumn{2}{|c|}{2009} \\
\hline & & Budget & Staff Proj. \\
\hline$\overline{R e v e n u e ~ a n d ~ g r a n t s ~}$ & 32.6 & 31.5 & 27.1 \\
\hline Revenue & 29.1 & 26.7 & 23.8 \\
\hline Mineral & 11.2 & 3.6 & 5.3 \\
\hline Nonmineral $1 /$ & 17.9 & 23.1 & 18.6 \\
\hline Grants & 3.5 & 4.6 & 3.3 \\
\hline Total Expenditure & 28.1 & 31.5 & 29.1 \\
\hline Recurrent & 18.2 & 18.5 & 18.4 \\
\hline Development & 6.0 & 13.1 & 10.7 \\
\hline o/w DSIP 2/ & 0.2 & 1.8 & 1.7 \\
\hline APE 3/ & 3.8 & 0.0 & 0.0 \\
\hline Overall balance & 4.5 & 0.0 & -2.0 \\
\hline Memorandum items: & & & \\
\hline Trust funds balance 4 / & 16.6 & 14.7 & 14.7 \\
\hline Estimated fiscal impulse & 5.2 & $\ldots$ & 6.5 \\
\hline
\end{tabular}

Sources: PNG authorities and Fund staff projections and estimates.

$1 /$ The 2009 budget records as revenue $\$ 600$ million kina previously accumulated in trust accounts. Under the IMF presentation, this amount is recorded as positive financing 2/ District Service Improvement Program.

$3 /$ Additional priority spending.

4/ Stock.

${ }^{1}$ Staff projections on expenditure for the 2009 are based on historical underspending in development due to implementation constraints. 
13. Staff noted that the use of trust funds in the 2009 budget was not fully consistent with the MTFS and questioned the efficacy of some planned public spending. A portion of the allocation of spending to provinces and districts will be financed with accumulated windfall revenue. Because there are no mechanisms to ensure that these resources will be directed toward public investment in MTDS priority areas, this is inconsistent with the MTFS. Given the outlook for commodity prices and thus the limited prospects for additional windfall revenues in the coming years, staff stressed the importance of safeguarding the accumulated revenues and using them effectively to achieve development needs.

Additionally, the lack of capacity to prioritize and manage projects, and the near absence of reporting and accountability in local governments raises concerns about the efficiency of such spending.

\section{The authorities were mindful about the importance of maintaining medium-} term sustainability, but pointed to political pressures to spend. In particular, the country's acute development needs alongside the large accumulated trust funds have generated demands to visibly increase spending at the local level, hence the increase in District Service Improvement Program (DSIP) spending. However, given the outlook for mineral revenues both in the short and the medium term, they acknowledged the risk to fiscal sustainability, particularly in light of the DSA analysis presented by staff.

\section{Staff advised that continued tax reform would help reduce budgetary} dependence on mineral revenues. Strengthening tax administration and rationalizing corporate tax incentives would improve nonmineral revenue buoyancy and efficiency. A number of tax concessions have been granted in the past in many sectors resulting in a growing list of ad hoc concessions that undermine the tax base. The authorities stressed that incentives were necessary to stimulate growth, but committed to maintain the current tax base. In the future, granting tax concessions on an ad hoc basis will be avoided and future tax concessions will only be granted under the existing laws.

\section{Discussions also focused on the implications for the medium-term fiscal position} of the planned public investment in the LNG project (Box 4). The mission advised that budget plans be cautious because the government's financial obligations associated with the project could put pressure on the country's debt position. Also, the mission emphasized the importance of channeling the dividends from the public's equity stake in the project through the budget to ensure that they are directed toward addressing development needs. 


\section{Box 4. GDP Impact of the LNG Project}

The peak impact of the LNG project is estimated to be an increase of 25 to 30 percent in

GDP. Production is expected to commence in late 2013, with a maximum capacity of about 60 million barrels of oil equivalent. The 30 -year project is estimated to increase GDP, through both direct and indirect channels, by about 15 to 20 percent. The impact during the 5-year construction phase will be relatively small. Accounting for the substantial income outflows, the project is expected to increase annual GNI by about 9 percent.

\begin{tabular}{|ll|}
\hline Total Project Cost & US\$11-13 billion \\
State's equity participation & US $\$ 1.1$ billion \\
State's completion guarantee & US $\$ 2.0$ billion \\
Capital investment & $55 \%$ of total cost \\
Labor investment & $45 \%$ of total cost \\
Construction phase & $85 \%$ of total cost \\
Production phase & $15 \%$ of total cost \\
Maximum Capacity & 60 mboe per year* \\
Impact on GDP (per year) & \\
Construction period & 0.8 percent of GDP \\
Peak production period & $25-30$ percent of GDP \\
Overall period & $15-20$ percent of GDP \\
\hline Source: PNG Treasury. & \\
* mboe: million barrel of oil equivalent.
\end{tabular}

\section{Monetary Policy_Guarding Against Persistently High Inflation}

17. Staff noted that the current monetary stance was appropriate, but underlined the need for monetary policy to react quickly to changing circumstances. Although imported inflation will fall rapidly given declining commodity prices, policy needs to ensure that domestic pressures do not keep inflation too high. In particular, the fiscal stimulus in the pipeline for 2009 and still rapid credit growth may fuel nontradables inflation going forward. With real lending rates expected to rise as headline inflation declines, staff advised the central bank to keep its policy rate on hold until there is more certainty about how domestic inflation pressures will evolve. However, with risks to inflation assessed as lying on the downside, staff stressed that the central bank should be prepared to loosen quickly if leading indicators suggest that domestic demand will slow sharply or the inflation outlook improves.

18. The authorities agreed broadly with this assessment, although they considered it unlikely that they would need to loosen monetary policy in the near term. They noted that domestic capacity is stretched and confidence has been supported by increased certainty that the LNG project will proceed. In the absence of official data on property prices, they pointed to anecdotal evidence of rapidly rising real estate prices as an indicator of the extent of domestic demand pressures. Furthermore, they noted that the magnitude of the planned fiscal easing and the increase in the minimum wage had the potential to impart significant domestic inflation pressure.

19. Staff supported the transfer of part of the government's trust accounts from private banks to the BPNG, and encouraged the quick transfer of the remaining accounts. Private sector credit growth, fueled by strong expansion in deposits, has added to 
domestic demand and further strained available resources. Staff reasoned that moving the public trust accounts to the BPNG was a cost-effective means of reducing liquidity and easing credit growth. ${ }^{3}$ The authorities agreed and noted that negotiations to transfer the remaining trust accounts were ongoing.

\section{Financial Sector-Coping with the Financial Turmoil}

20. There was agreement that the financial sector is insulated from the direct effects of the global financial market turmoil. With banks funded primarily via domestic deposits, the tight conditions in international capital markets are not affecting their liquidity.

\section{Staff and the authorities saw asset quality as the greatest risk to financial} stability. With export incomes expected to decline sharply owing to falling commodity prices, concerns about debt-servicing capabilities have risen, particularly in light of the rapid pace of credit growth over the last few years. It was noted that credit expansion has been largely to banks' long-term customers, somewhat mitigating these concerns. The authorities noted that the downturn could slow credit growth as both credit demand and deposit growth ease. They also reported progress on credit monitoring, including the establishment of the credit and data bureau that provides data to inform credit decisions. Regarding staff's concerns that the recent revival of the Development Bank could see funds directed by political interests generating hidden fiscal liabilities, the authorities noted that the Development Bank has remained both small and profitable.

22. To date, the superannuation funds have weathered the turmoil well. Despite significant holdings of mining, oil, and other equities that have dropped substantially in value, these funds were still expecting positive returns in 2008. This reflects continued strong performance of other domestic investments, particularly real estate.

\section{Staff reiterated that the level of financial intermediation remains very low} relative to peers - a constraint on private nonmineral sector growth. Credit to the private sector represents less than 20 percent of GDP, largely due to structural rigidities, including weak enforcement of contracts and credit rights. The authorities concurred and hoped that the Financial Sector Assessment Program (FSAP), tentatively scheduled for late-2009, would provide impetus for reform. They also confirmed their willingness to undertake a selfassessment of the financial sector prior to the FSAP.

\footnotetext{
${ }^{3}$ The government's trust accounts are an inexpensive source of funds for the banks as interest of only 1 percent is paid on these deposits.
} 


\section{E. Assessing the Equilibrium Real Exchange Rate and External Stability}

24. In line with the recent deterioration in the terms of trade, staff estimates suggest mild overvaluation of the kina (Box 5). The mission encouraged the authorities to continue to shift toward greater exchange rate flexibility. Allowing the currency to adjust in response to the sharp decline in commodity prices would help offset the impact on export incomes and safeguard foreign reserves. The authorities acknowledged the benefits of allowing the exchange rate to adjust given the decline in commodities prices. However, they noted that given the extraordinary global volatility and high domestic inflation, slowing exchange rate adjustment was key to anchoring inflation expectations.

\section{External debt has decreased, but negative terms-of-trade shocks and} uncertainties about other liabilities raise concerns about long-term fiscal sustainability. Large current account surpluses in recent years and the early repayment of debt have resulted in a significant improvement in the external debt position. External debt declined to about 27 percent of GDP in 2008. The debt sustainability analysis suggests that the risk of debt distress is moderate (Appendix 1). ${ }^{4}$ However, the scale of broader public-sector obligations (i.e., borrowing and guarantees associated with the LNG project, the large unfunded pension liability, the uncertain magnitudes of state-owned-enterprise debt, and the government's commitments under the memorandum of agreement with landowners) combined with vulnerability to deteriorations in the terms of trade suggests that highly unfavorable debt dynamics could arise.

\footnotetext{
${ }^{4}$ Alternative scenarios include the LNG-project scenario and other liabilities.
} 


\section{F. Fostering Sustainable, Broad-Based Growth}

26. The implementation of structural reforms has slowed. The Medium-Term Development Strategy (MTDS), spanning 2005-10, has correctly recognized the need to shift the sources of growth toward the private nonmineral sector. The strategy stresses the importance of increasing exports of nonminerals and manufactures. The required improvements that will enable Papua New Guinea to catch up with its peers include addressing a weak transportation system, encouraging private micro-credit facilities, improving basic utilities such as power and telecommunications services, increasing human capital, and reducing crime. However, decisive actions have been

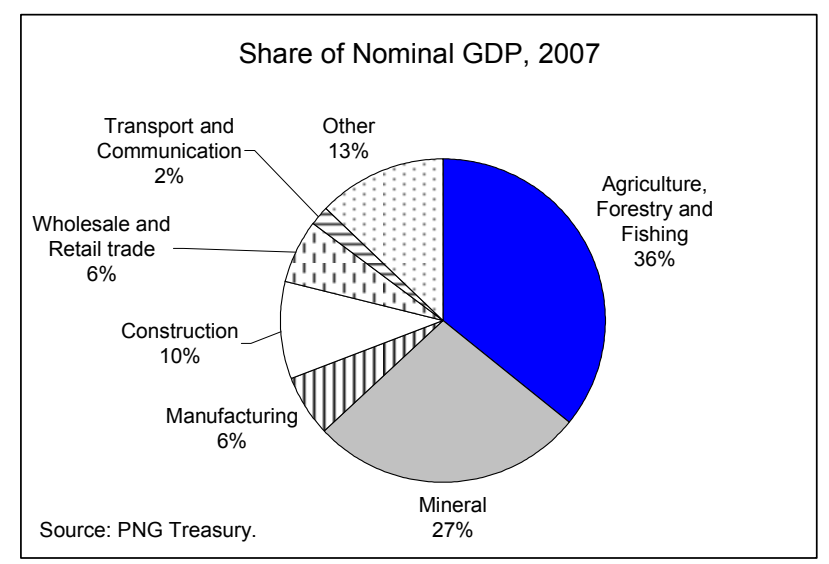
lacking, with the exception of the communication sector. The government plans to undertake a review of the development strategy in late 2009. The extraordinary improvements in communication services, following the introduction of competition in the cellular phone market, illustrate the benefits of continued reform.

27. The authorities agreed with this assessment. They noted that the political commitment toward accelerating these reforms has been minimal because focus has been almost entirely directed toward the LNG project.

28. Staff underscored that the prospective LNG project could provide a permanent boost to GDP growth, provided the resulting revenues and dividends were directed toward addressing development needs. The mineral sector operates as an "enclave" with limited direct spillovers to other sectors. The key linkage to the nonmineral sector of the economy is via revenues to the public budget. Therefore, while it is crucial to directly encourage private activity in the nonmineral industries, nonmineral sector growth will continue to be influenced by growth in the mineral sector and the effective use of the resulting public resources. If the LNG project goes forward, it will result in a large, one-time increase in the level of GDP once production commences. Without significant progress on the reform front, GDP growth will revert to trend in the following years. To permanently raise long-term growth in the nonmineral sector, the resulting revenues and public ownership proceeds must be channeled through the budget and directed toward effectively addressing development needs.

29. The mission stressed that notable improvements to public service delivery and the private investment climate were central to addressing developments needs. Enforcing contracts, dealing with licenses, and obtaining credit are relatively more cumbersome compared to other countries in the region, according to the World Bank ease-of- 
doing-business database. Further, security issues continue to be a significant barrier to private sector activity.

\section{G. Other Issues}

30. There has been only limited progress on improving the quality and timeliness of macroeconomic data. The authorities reported that the department of National Planning and Monitoring, currently responsible for the National Statistic Office (NSO), has been unwilling to transfer the compilation and dissemination of economic statistics from the NSO to the BPNG, as advised by the December 2007 STA mission. Staff reiterated that intensive efforts are needed to address shortcomings in the quality and timeliness of the macroeconomic data. The authorities agreed, but offered no indication of when or how the impasse might be resolved.

\section{Staff ApPRAisal}

31. Papua New Guinea was in a relatively favorable position at the onset of the global financial crisis. Windfall mineral revenues had been largely saved. Large current account surpluses and the early repayment of public debt had improved the external debt position. Exchange rate flexibility had increased and the banking system had only limited exposure to global financial markets.

32. Yet, the deterioration in international economic conditions is having an impact, albeit milder than in many other countries. The global slowdown is taking its toll mainly through lower export revenues, owing to the collapse in commodity prices, worsening both domestic and external balances. However, despite the highly synchronized nature of the global downturn, some idiosyncratic factors such as the prospective LNG project and the relative insulation of the banks from global financial markets are buffering the impact on Papua New Guinea.

33. The monetary stance is appropriate, but caution is needed moving ahead. Despite the decline in food and energy prices, there are risks that domestic price pressures could prevent a rapid decline in inflation. However, with the balance of risks to inflation on the downside because of the deteriorating external environment, the central bank should be prepared to loosen quickly if a larger-than expected negative domestic impact materializes.

34. The new Medium-Term Fiscal Strategy, if fully implemented, will help maintain macroeconomic stability. Insulating recurrent spending from abnormal fluctuations in mineral revenues will facilitate both public and private planning and help guard against procyclical fiscal policy. However, macroeconomic stability would be enhanced if the monetary and fiscal authorities cooperated to ensure that the cyclical position of the economy determined the magnitude of annual spending from trust accounts. 
35. A looser fiscal policy seems warranted in 2009, but concerns remain about the magnitude and the quality of spending. Although inflation is forecast to moderate over 2009, capacity pressures could still keep it uncomfortably high. Therefore, to ensure that public demand does not stimulate inflation, it would be prudent to reduce public spending in 2009 so as to achieve a balanced budget by staff definition. In addition, should the planned level of expenditure be maintained over the medium term, fiscal sustainability will be threatened. Moreover, with acute capacity constraints and almost no oversight or accountability mechanism in place, the expected increase in spending at the district level raises concern about achieving appropriate value for money.

36. More discipline is needed in spending the mineral windfall accumulated over the last few years. The windfall should be safeguarded and directed toward achieving the Medium-Term Development Strategy objectives and be available to support growth should the impact of the global slowdown be larger than expected.

37. Indicators suggest that the currency is mildly overvalued. Given the sharp decline in commodity prices, the currency should be allowed to adjust to help offset the impact on export incomes. This policy would also help to safeguard foreign currency reserves.

38. The financial sector has been relatively immune to the global financial crisis. With banks funded primarily via domestic deposits, the tight conditions in international capital markets are not affecting their liquidity. However, the impact of declining commodity prices on export incomes could stress debt-servicing capabilities, driving up nonperforming loans. Therefore, banks should maintain strict lending standards and monitor borrowers' servicing abilities carefully.

39. The pace of structural reform must accelerate. To make meaningful progress toward achieving development objectives, the public-sector reform program on health, education, and law and order needs to be reinvigorated. Complete transparency of the financial conditions of state-owned enterprises and full transfer of their returns to general government revenue will be necessary to ensure that the government has the resources to implement the reform agenda. If the LNG project proceeds, to permanently raise long-term growth in the nonmineral sector, the resulting revenues and public ownership proceeds must be channeled through the budget and directed toward effectively addressing development needs.

40. Macroeconomic data needs to improve. The government must press ahead with Fund recommendations on the compilation and dissemination of economic data as they form the cornerstone for sound macroeconomic policy.

41. Staff recommends the next Article IV consultation be on the standard 12-month cycle. 
Table 1. Papua New Guinea: Selected Economic Indicators, 2005-09

$\begin{array}{ll}\text { Nominal GDP (2007): } & \text { US } \$ 6.39 \text { billion } \\ \text { Population (2007): } & 6.3 \text { million } \\ \text { GDP per capita (2007): } & \text { US } \$ 1,012 \\ \text { Quota: } & \text { SDR } 131.6 \text { million }\end{array}$

\begin{tabular}{|c|c|c|c|c|c|}
\hline & 2005 & 2006 & 2007 & 2008 & 2009 \\
\hline & & & & Est. & Proj. \\
\hline \multicolumn{6}{|l|}{ Real sector (percent change) } \\
\hline Real GDP growth & 3.6 & 2.6 & 6.5 & 7.0 & 3.9 \\
\hline Mineral & 5.0 & -5.9 & 0.2 & 4.8 & 2.6 \\
\hline Nonmineral & 3.4 & 3.8 & 7.3 & 7.2 & 4.1 \\
\hline $\mathrm{CPI}$ (annual average) & 1.8 & 2.4 & 0.9 & 10.7 & 8.2 \\
\hline $\mathrm{CPI}$ (end-period) & 4.7 & -0.9 & 3.2 & 11.2 & 5.3 \\
\hline \multicolumn{6}{|l|}{ Central government operations (percent of GDP) } \\
\hline Revenue and grants & 34.9 & 36.7 & 37.3 & 32.7 & 27.1 \\
\hline Expenditure and net lending & 31.2 & 30.0 & 29.2 & 28.2 & 29.1 \\
\hline Overall balance, cash basis (including grants) $1 /$ & 3.7 & 6.7 & 8.2 & 4.5 & -2.0 \\
\hline Overall balance, cash basis (including grants) $2 /$ & 3.8 & 5.6 & 7.2 & 4.5 & -2.0 \\
\hline Nonmineral balance $2 /$ & -4.7 & -7.6 & -6.8 & -6.7 & -7.2 \\
\hline \multicolumn{6}{|l|}{ Money and credit (end-period percentage change) } \\
\hline Domestic credit & 8.6 & 19.4 & 5.5 & -3.1 & 15.7 \\
\hline Credit to the private sector & 23.7 & 38.2 & 34.4 & 41.0 & 21.3 \\
\hline Broad money & 29.5 & 38.9 & 27.8 & 11.4 & 17.7 \\
\hline Interest rate (182-day T-bills; period average) & 3.8 & 3.7 & 4.4 & 6.0 & $\ldots$ \\
\hline \multicolumn{6}{|l|}{ Balance of payments (millions of U.S. dollars) } \\
\hline Exports, f.o.b. & 3,278 & 4,207 & 4,750 & 5,397 & 4,197 \\
\hline Of which: Mineral & 2,467 & 3,391 & 3,709 & 4,104 & 3,063 \\
\hline Imports, c.i.f. & $-2,462$ & $-2,805$ & $-3,331$ & $-3,794$ & $-3,521$ \\
\hline Current account (including grants) & 205 & 128 & 112 & 228 & -546 \\
\hline (In percent of GDP) & 4.1 & 2.3 & 1.8 & 2.8 & -6.7 \\
\hline Overall balance & 315 & 661 & 657 & 5 & 50 \\
\hline \multicolumn{6}{|l|}{ Reserves and external debt (end-period; millions of U.S. dollars) } \\
\hline Net international reserves & 765 & 1,425 & 2,083 & 2,090 & 2,140 \\
\hline (In months of goods and services imports) & 2.4 & 3.8 & 4.7 & 4.3 & 4.7 \\
\hline Public external debt-service-ratio (percent of exports) 3/ & 6.0 & 3.5 & 4.1 & 2.5 & 2.1 \\
\hline Public external debt-to-GDP ratio (in percent) $3 /$ & 25.4 & 21.1 & 16.7 & 12.2 & 14.7 \\
\hline \multicolumn{6}{|l|}{ Exchange rates } \\
\hline US\$/kina (period-average) & 0.3273 & 0.3288 & 0.3416 & 0.3731 & $\ldots$ \\
\hline US\$/kina (end-period) & 0.3230 & 0.3310 & 0.3618 & 0.3735 & $\ldots$ \\
\hline NEER $(2000=100$, end-period $)$ & 80.7 & 78.0 & 77.7 & 95.0 & $\ldots$ \\
\hline $\operatorname{REER}(2000=100$, end-period $)$ & 104.2 & 98.0 & 98.7 & 135.2 & $\ldots$ \\
\hline Nominal GDP (millions of kina) & 15,195 & 17,132 & 18,716 & 22,246 & 22,362 \\
\hline
\end{tabular}

Sources: Data provided by the Papua New Guinea authorities; and Fund staff estimates and projections.

1/ Measured from above the line in the fiscal accounts.

2/ Measured from below the line in the fiscal accounts.

$3 /$ Includes central government, central bank external debt, and statutory authorities.

\section{CInternational Monetary Fund. Not for Redistribution}


Table 2. Papua New Guinea: Balance of Payments, 2007-13

(In millions of U.S. dollars)

\begin{tabular}{|c|c|c|c|c|c|c|c|}
\hline & 2007 & 2008 & 2009 & 2010 & 2011 & 2012 & 2013 \\
\hline & & Est. & \multicolumn{5}{|c|}{ Proj. } \\
\hline Current account balance & 112 & 228 & -546 & -393 & -373 & -346 & -283 \\
\hline Mineral & 1,368 & 1,514 & 630 & 875 & 942 & 1,050 & 1,145 \\
\hline Nonmineral & $-1,255$ & $-1,286$ & $-1,176$ & $-1,268$ & $-1,315$ & $-1,395$ & $-1,429$ \\
\hline Trade balance & 1,419 & 1,604 & 676 & 887 & 950 & 1,015 & 1,091 \\
\hline Exports (f.o.b.) & 4,750 & 5,397 & 4,197 & 4,646 & 4,920 & 5,130 & 5,298 \\
\hline Mineral & 3,709 & 4,104 & 3,063 & 3,481 & 3,682 & 3,885 & 4,021 \\
\hline Nonmineral & 1,042 & 1,293 & 1,134 & 1,165 & 1,238 & 1,244 & 1,277 \\
\hline Imports (c.i.f.) & $-3,331$ & $-3,794$ & $-3,521$ & $-3,759$ & $-3,970$ & $-4,114$ & $-4,207$ \\
\hline Mineral & -990 & $-1,219$ & $-1,207$ & $-1,315$ & $-1,397$ & $-1,442$ & $-1,450$ \\
\hline Nonmineral & $-2,341$ & $-2,575$ & $-2,314$ & $-2,444$ & $-2,573$ & $-2,673$ & $-2,756$ \\
\hline Services & $-1,057$ & $-1,115$ & $-1,071$ & $-1,125$ & $-1,164$ & $-1,200$ & $-1,211$ \\
\hline Income & -601 & -578 & -455 & -474 & -493 & -513 & -534 \\
\hline Current Transfers & 350 & 318 & 302 & 319 & 334 & 352 & 371 \\
\hline Official & 316 & 284 & 271 & 281 & 293 & 307 & 323 \\
\hline Private & 34 & 33 & 31 & 38 & 41 & 44 & 48 \\
\hline Capital and financial account balance & 497 & -222 & 596 & 496 & 492 & 475 & 414 \\
\hline Direct investment & 462 & 277 & 263 & 277 & 291 & 306 & 322 \\
\hline Other investment & 35 & -500 & 333 & 219 & 201 & 168 & 91 \\
\hline Medium- and long-term loan & -217 & -100 & 139 & 57 & 65 & 83 & 49 \\
\hline Official (net) & -131 & -82 & 161 & 70 & 79 & 98 & 74 \\
\hline Private capital flows (net) & -86 & -17 & -22 & -12 & -14 & -15 & -25 \\
\hline Commercial banks & -273 & -110 & 98 & 68 & 42 & -10 & -55 \\
\hline Other & 525 & -290 & 96 & 94 & 94 & 95 & 98 \\
\hline Net errors and omissions & 48 & 0 & 0 & 0 & 0 & 0 & 0 \\
\hline Overall balance & 657 & 5 & 50 & 103 & 119 & 129 & 131 \\
\hline Financing & -657 & -7 & -50 & -103 & -119 & -129 & -131 \\
\hline Reserve assets & -659 & -5 & -50 & -103 & -119 & -129 & -131 \\
\hline Use of IMF credit & 0 & 0 & 0 & 0 & 0 & 0 & 0 \\
\hline Other foreign liabilities & 2 & -2 & 0 & 0 & 0 & 0 & 0 \\
\hline \multicolumn{8}{|l|}{ Memorandum items: } \\
\hline Current account (in percent of GDP) & 1.8 & 2.8 & -6.7 & -4.7 & -4.3 & -3.9 & -3.1 \\
\hline Mineral & 21.4 & 18.7 & 7.7 & 10.4 & 11.0 & 11.9 & 12.6 \\
\hline Nonmineral & -19.7 & -15.9 & -14.3 & -15.1 & -15.3 & -15.8 & -15.7 \\
\hline \multicolumn{8}{|l|}{ Net international reserves (end-year) } \\
\hline In millions of U.S. dollars & 2,083 & 2,090 & 2,140 & 2,242 & 2,361 & 2,490 & 2,621 \\
\hline \multicolumn{8}{|l|}{ Gross official reserves (end-year) } \\
\hline In millions of U.S. dollars & 2,087 & 2,092 & 2,142 & 2,244 & 2,363 & 2,492 & 2,623 \\
\hline In months of imports of goods and nonfactor services & 4.8 & 4.3 & 4.7 & 4.7 & 4.7 & 4.8 & 5.0 \\
\hline Public external debt-service-exports ratio (in percent) $1 /$ & 4.1 & 2.5 & 2.1 & 2.1 & 2.0 & 1.9 & 1.9 \\
\hline Public external debt-GDP ratio (in percent) $1 /$ & 16.7 & 12.2 & 14.7 & 15.1 & 15.7 & 16.3 & 16.7 \\
\hline
\end{tabular}

Sources: Data provided by the Papua New Guinea authorities; and Fund staff estimates and projections.

1/ Public external debt includes central government, central bank external debt, and statutory authorities. 
Table 3. Papua New Guinea: Medium-Term Scenario, 2007-13

\begin{tabular}{|c|c|c|c|c|c|c|c|}
\hline & 2007 & 2008 & 2009 & 2010 & 2011 & 2012 & 2013 \\
\hline & & Est. & \multicolumn{5}{|c|}{ Projections } \\
\hline \multicolumn{8}{|l|}{ Growth and prices (change in percent) } \\
\hline Real GDP & 6.5 & 7.0 & 3.9 & 3.7 & 3.3 & 3.0 & 2.4 \\
\hline Mineral & 0.2 & 4.8 & 2.6 & 4.2 & 3.0 & 0.1 & -2.4 \\
\hline Nonmineral & 7.3 & 7.2 & 4.1 & 3.7 & 3.4 & 3.3 & 2.9 \\
\hline CPI (period average) & 0.9 & 10.7 & 8.2 & 5.0 & 4.6 & 4.2 & 3.7 \\
\hline $\mathrm{CPI}$ (end-period) & 3.2 & 11.2 & 5.3 & 4.8 & 4.5 & 4.0 & 3.5 \\
\hline \multicolumn{8}{|l|}{ Central government operations (in percent of GDP) } \\
\hline Total revenue and grants & 37.3 & 32.7 & 27.1 & 26.5 & 26.6 & 27.0 & 27.3 \\
\hline Total revenue & 33.5 & 29.1 & 23.8 & 23.2 & 23.2 & 23.5 & 23.7 \\
\hline Of which: Mineral tax revenue & 12.8 & 10.2 & 4.8 & 4.3 & 4.1 & 4.3 & 4.3 \\
\hline Grants & 3.9 & 3.5 & 3.3 & 3.3 & 3.4 & 3.5 & 3.6 \\
\hline Total expenditure & 29.2 & 28.2 & 29.1 & 28.1 & 28.1 & 28.0 & 28.6 \\
\hline Primary balance $1 /$ & 9.1 & 6.3 & -0.1 & 0.0 & 0.2 & 0.7 & 0.5 \\
\hline Nonmineral balance $1 /$ & -6.8 & -6.7 & -7.2 & -6.2 & -6.0 & -5.7 & -6.0 \\
\hline Overall balance $1 /$ & 7.2 & 4.5 & -2.0 & -1.5 & -1.5 & -1.0 & -1.3 \\
\hline Domestic financing (net) 2/ & -5.0 & -2.6 & 1.9 & 0.7 & 0.6 & -0.1 & 0.5 \\
\hline Foreign financing (net) & -2.1 & -1.9 & 0.1 & 0.8 & 0.8 & 1.1 & 0.8 \\
\hline Gross public debt (in percent of GDP) $3 /$ & 33.7 & 26.6 & 29.5 & 29.4 & 29.6 & 29.9 & 29.8 \\
\hline Domestic & 17.0 & 14.4 & 14.8 & 14.3 & 13.9 & 13.6 & 13.2 \\
\hline External & 16.7 & 12.2 & 14.7 & 15.1 & 15.7 & 16.3 & 16.7 \\
\hline \multicolumn{8}{|l|}{ Balance of payments (in millions of U.S. dollars) } \\
\hline Exports, f.o.b. & 4,750 & 5,397 & 4,197 & 4,646 & 4,920 & 5,130 & 5,298 \\
\hline Of which: Mineral & 3,709 & 4,104 & 3,063 & 3,481 & 3,682 & 3,885 & 4,021 \\
\hline Imports, c.i.f. & $-3,331$ & $-3,794$ & $-3,521$ & $-3,759$ & $-3,970$ & $-4,114$ & $-4,207$ \\
\hline Current account & 112 & 228 & -546 & -393 & -373 & -346 & -283 \\
\hline (In percent of GDP) & 1.8 & 2.8 & -6.7 & -4.7 & -4.3 & -3.9 & -3.1 \\
\hline Overall balance (including exceptional financing) & 657 & 5 & 50 & 103 & 119 & 129 & 131 \\
\hline Net official reserves (in millions of U.S. dollars) & 2,083 & 2,090 & 2,140 & 2,242 & 2,361 & 2,490 & 2,621 \\
\hline (In months of goods and services imports, c.i.f.) & 4.7 & 4.3 & 4.7 & 4.7 & 4.7 & 4.8 & 5.0 \\
\hline (In months of nonmining imports, c.i.f.) & 10.7 & 9.7 & 11.1 & 11.0 & 11.0 & 11.2 & 11.4 \\
\hline Public external debt service-export ratio (in percent) $3 /$ & 4.1 & 2.5 & 2.1 & 2.1 & 2.0 & 1.9 & 1.9 \\
\hline \multicolumn{8}{|l|}{ Memorandum items: } \\
\hline Nominal GDP (in millions of U.S. dollars) & 6,387 & 8,092 & 8,200 & 8,390 & 8,594 & 8,820 & 9,078 \\
\hline \multicolumn{8}{|l|}{ Assumed commodity prices: $4 /$} \\
\hline Gold (US\$/oz) & 697 & 872 & 880 & 890 & 905 & 925 & 940 \\
\hline Copper (US\$/ton) & 7,132 & 6,963 & 3,500 & 3,800 & 4,000 & 4,200 & 4,400 \\
\hline Oil (US\$/barrel) & 71 & 97 & 50 & 60 & 65 & 67 & 69 \\
\hline
\end{tabular}

Sources: Department of Treasury; Bank of Papua New Guinea; and Fund staff estimates and projections.

$1 /$ Measured from below-the-line in the fiscal accounts.

2/ Includes changes in check float.

$3 /$ Includes central government, central bank external debt, and statutory authorities.

4/ January 2009 WEO projection. 
Table 4. Papua New Guinea: Summary Accounts of the Banking System, 2005-09

\begin{tabular}{|c|c|c|c|c|c|}
\hline & 2005 & 2006 & 2007 & 2008 & $\begin{array}{c}2009 \\
\text { Proj. }\end{array}$ \\
\hline Bank of Papua New Guinea & \multicolumn{5}{|c|}{ (In millions of kina; end of period) } \\
\hline Net foreign assets & 2,367 & 4,319 & 5,908 & 5,317 & 5,971 \\
\hline Foreign assets & 2,368 & 4,326 & 5,919 & 5,322 & 5,976 \\
\hline Foreign liabilities & 1 & 6 & 11 & 4 & 6 \\
\hline Net domestic assets & $-1,432$ & $-3,181$ & $-4,067$ & $-3,697$ & $-3,629$ \\
\hline Domestic credit & -502 & -601 & $-1,103$ & $-1,711$ & $-2,277$ \\
\hline Net credit to government & -538 & -659 & $-1,134$ & $-1,742$ & $-2,309$ \\
\hline Claims & 108 & 144 & 203 & 196 & 240 \\
\hline Central government deposits & -646 & -803 & $-1,337$ & $-1,937$ & $-2,549$ \\
\hline Credit to other sectors & 36 & 58 & 32 & 31 & 32 \\
\hline Other items, net & -929 & $-2,580$ & $-2,964$ & $-1,986$ & $-1,352$ \\
\hline Reserve money & 935 & 1,138 & 1,842 & 1,621 & 2,342 \\
\hline Currency in circulation & 606 & 693 & 823 & 851 & 983 \\
\hline Deposits of other depository corporations & 322 & 442 & 1,016 & 767 & 1,356 \\
\hline Other deposits & 8 & 3 & 3 & 3 & 3 \\
\hline Monetary Survey & \multicolumn{5}{|c|}{ (In millions of kina; end of period) } \\
\hline Net foreign assets & 2,929 & 4,648 & 7,073 & 6,204 & 7,378 \\
\hline Net domestic assets & 2,141 & 2,392 & 1,922 & 3,813 & 6,523 \\
\hline Domestic credit & 3,329 & 3,975 & 4,194 & 4,065 & 5,690 \\
\hline Net credit to central government & 1,114 & 966 & 171 & $-1,585$ & $-1,051$ \\
\hline Claims on other sectors & 2,215 & 3,009 & 4,023 & 5,651 & 6,741 \\
\hline Claims on the private sector & 2,133 & 2,947 & 3,961 & 5,584 & 6,679 \\
\hline Other items, net & $-1,188$ & $-1,582$ & $-2,272$ & -253 & 833 \\
\hline Broad money & 5,069 & 7,041 & 8,995 & 10,017 & 13,901 \\
\hline Narrow money & 3,017 & 3,792 & 4,923 & 5,520 & 8,793 \\
\hline Currency outside banks & 445 & 520 & 608 & 605 & 762 \\
\hline Demand deposits & 2,572 & 3,272 & 4,316 & 4,916 & 8,031 \\
\hline Quasi money & 2,052 & 3,249 & 4,072 & 4,496 & 5,107 \\
\hline & \multicolumn{5}{|c|}{ (Annual percentage change) } \\
\hline Net foreign assets & 35.3 & 58.7 & 52.2 & -12.3 & 5.8 \\
\hline Net domestic assets & 22.3 & 11.8 & -19.7 & 98.4 & 34.8 \\
\hline Net domestic credit & 8.6 & 19.4 & 5.5 & -3.1 & 15.7 \\
\hline Of which: Private sector & 23.7 & 38.2 & 34.4 & 41.0 & 21.3 \\
\hline Broad money & 29.5 & 38.9 & 27.8 & 11.4 & 17.7 \\
\hline \multicolumn{6}{|l|}{ Memorandum items: } \\
\hline Reserve money (percentage change) & 7.4 & 21.7 & 61.8 & -12.0 & 15.5 \\
\hline Gross international reserves (in millions of US dollars) & 765 & 1,427 & 2,087 & 2,092 & 2,142 \\
\hline Broad money velocity & 3.0 & 2.4 & 2.1 & 2.2 & 1.6 \\
\hline Nominal nonmineral GDP/Broad money & 2.3 & 1.8 & 1.5 & 1.6 & 1.2 \\
\hline
\end{tabular}

Sources: Data provided by the Papua New Guinea authorities; and Fund staff estimates and projections.

\section{CInternational Monetary Fund. Not for Redistribution}


Table 5. Papua New Guinea: Summary of Central Government Operations, 2007-09

\begin{tabular}{|c|c|c|c|c|c|}
\hline & \multirow[t]{2}{*}{2007} & \multicolumn{2}{|c|}{2008} & \multicolumn{2}{|c|}{2009} \\
\hline & & Auth. Proj & Staff Proj. & Budget & Staff Proj. \\
\hline & \multicolumn{5}{|c|}{ (In percent of GDP) } \\
\hline Revenue and grants & 37.3 & 35.8 & 32.6 & 31.5 & 27.1 \\
\hline Revenue & 33.5 & 30.6 & 29.1 & 26.7 & 23.8 \\
\hline Tax revenue & 31.3 & 28.4 & 26.9 & 24.6 & 22.3 \\
\hline Mineral taxes & 12.8 & 11.2 & 10.2 & 3.0 & 4.8 \\
\hline Nonmineral taxes & 18.5 & 17.2 & 16.7 & 21.7 & 17.5 \\
\hline Nontax revenue & 2.2 & 2.2 & 2.2 & 2.1 & 1.5 \\
\hline o/w mineral non-tax revenue & 1.2 & 1.1 & 1.0 & 0.6 & 0.5 \\
\hline Grants & 3.9 & 5.2 & 3.5 & 4.6 & 3.3 \\
\hline Total expenditure and net lending & 29.2 & 35.8 & 28.1 & 31.5 & 29.1 \\
\hline Recurrent expenditure & 19.3 & 16.9 & 18.2 & 18.5 & 18.4 \\
\hline National departments & 11.8 & 10.6 & 11.3 & 11.2 & 10.9 \\
\hline Provinces & 4.2 & 3.6 & 4.0 & 4.2 & 4.3 \\
\hline Statutory authorities & 1.3 & 1.1 & 1.2 & 1.2 & 1.3 \\
\hline Interest & 2.0 & 1.7 & 1.8 & 1.9 & 1.9 \\
\hline Domestic & 1.3 & 1.3 & 1.2 & 1.4 & 1.4 \\
\hline Foreign & 0.6 & 0.4 & 0.5 & 0.4 & 0.5 \\
\hline Development expenditures and net lending & 9.9 & 18.9 & 9.9 & 13.1 & 10.7 \\
\hline Development expenditure & 9.9 & 18.9 & 9.9 & 12.1 & 10.7 \\
\hline Foreign financed & 4.4 & 5.9 & 3.7 & 5.5 & 4.5 \\
\hline Domestically funded & 5.5 & 13.0 & 6.2 & 6.5 & 6.2 \\
\hline o/w "Additional Priority Expenditures" & 2.9 & 10.6 & 3.8 & 0.0 & 0.0 \\
\hline Net lending & 0.0 & 0.0 & 0.0 & 0.0 & 0.0 \\
\hline Overall balance (from above the line) & 8.2 & 0.0 & 4.5 & 0.0 & -2.0 \\
\hline Overall balance (from below the line) & 7.2 & 1.0 & 4.5 & 0.0 & -2.0 \\
\hline Financing & -7.2 & -1.0 & -4.5 & 0.0 & 2.0 \\
\hline External financing (net) & -2.1 & -1.4 & -1.9 & -0.3 & 0.1 \\
\hline Disbursements & 0.5 & 0.8 & 0.2 & 0.9 & 1.2 \\
\hline Amortization & -2.7 & -2.1 & -2.0 & -1.2 & -1.1 \\
\hline Domestic financing (net) & -5.0 & 0.4 & -2.6 & 0.3 & 1.9 \\
\hline \multicolumn{6}{|l|}{ Memorandum items: } \\
\hline Nonmineral balance (below the line) & -6.8 & -11.3 & -6.7 & -3.6 & -7.2 \\
\hline Nominal GDP (in millions of kina) & 18,716 & 21,554 & 22,291 & 21,161 & 22,364 \\
\hline
\end{tabular}

Sources: Data provided by the Papua New Guinea authorities; and Fund staff estimates and projections. 
Table 6. Papua New Guinea: Indicators of External Vulnerability, 2005-09

(In percent of GDP, unless otherwise indicated)

\begin{tabular}{|c|c|c|c|c|c|}
\hline & \multirow[t]{2}{*}{2005} & \multirow[t]{2}{*}{2006} & \multirow[t]{2}{*}{2007} & 2008 & 2009 \\
\hline & & & & \multicolumn{2}{|c|}{ Proj. } \\
\hline \multicolumn{6}{|l|}{ Financial indicators } \\
\hline Gross public debt 1/ 2/ & 47.7 & 39.1 & 33.7 & 26.6 & 29.5 \\
\hline Broad money (percent change, 12-month basis) & 29.5 & 38.9 & 27.8 & 11.4 & 17.7 \\
\hline Private sector credit (percent change, 12 month basis) & 23.7 & 38.2 & 34.4 & 41.0 & 21.3 \\
\hline Interest rate (182-day T-bills; period average) & 3.8 & 3.7 & 4.4 & 6.0 & $\ldots$ \\
\hline \multicolumn{6}{|l|}{ External indicators } \\
\hline Exports (percent change, 12-month basis in U.S. dollars) & 28.4 & 28.3 & 12.9 & 13.6 & -22.2 \\
\hline Imports (percent change, 12-month basis in U.S. dollars) & 37.2 & 13.9 & 18.8 & 13.9 & -7.2 \\
\hline Current account balance & 4.2 & 2.3 & 1.8 & 2.8 & -6.7 \\
\hline Capital and financial account balance (millions of U.S. dollars) & 155.9 & 503.7 & 496.9 & -222.5 & 596.1 \\
\hline Of which: Inward foreign direct investment & 67.9 & 193.1 & 462.1 & 277.1 & 263.2 \\
\hline Gross official reserves (millions of U.S. dollars) & 764.9 & 1427.4 & 2086.6 & 2092.0 & 2141.8 \\
\hline Commerical bank foreign assets (millions of U.S. dollars) & 212.4 & 141.8 & 458.5 & 374.5 & 562.3 \\
\hline Commerical bank foreign liabilities (millions of U.S. dollars) & 31.0 & 33.2 & 47.8 & 43.3 & 58.1 \\
\hline Gross official reserves (months of nonmineral imports, c.i.f.) & 5.1 & 8.2 & 10.7 & 9.7 & 11.1 \\
\hline Broad money to gross reserves (ratio) & 2.1 & 1.6 & 1.5 & 1.4 & 2.3 \\
\hline Total short-term external debt to reserves (percent) $3 /$ & 4.1 & 2.3 & 2.3 & 2.1 & 2.7 \\
\hline Public external debt to GDP ratio (in percent) & 25.4 & 21.1 & 16.7 & 12.2 & 14.7 \\
\hline Public external debt service to exports (percent) & 6.0 & 3.5 & 4.1 & 2.5 & 2.1 \\
\hline Exchange rate (per U.S. dollar; period average) & 3.1 & 3.0 & 2.9 & 2.7 & $\ldots$ \\
\hline \multicolumn{6}{|l|}{ Financial market indicators } \\
\hline \multicolumn{6}{|l|}{ Foreign currency long-term government debt rating $1 /$} \\
\hline Moody's 4/ & B1(stab.) & $\mathrm{Ba} 2$ & $\mathrm{Ba} 2$ & $\mathrm{Ba} 2$ & $\ldots$ \\
\hline Standard \& Poors $5 /$ & B(pos.) & B & $\mathrm{B}+$ & $\mathrm{B}+$ & $\ldots$ \\
\hline
\end{tabular}

Sources: Department of Treasury; Bank of Papua New Guinea; and Fund staff estimates and projections.

$1 /$ End of period.

2/ Includes central government, central bank external debt, and statutory authorities.

$3 /$ Covers only banking system short-term external debt.

4/ Initial rating of B1 (stable) in January 1999.

5/ Initial rating of B+ (stable) in January 1999. The rating was upgraded to B+ in September 2007. 
Table 7. Papua New Guinea: Millennium Development Goals Progress, 1990-2007

\begin{tabular}{|c|c|c|c|c|c|}
\hline & 1990 & 1995 & 2000 & 2005 & 2007 \\
\hline \multicolumn{6}{|l|}{ Goal 1: Eradicate extreme poverty and hunger } \\
\hline \multicolumn{6}{|c|}{ Target 1: Halve, between 1990 and 2015, the proportion of people whose income is less than $\$ 1$ a day } \\
\hline \multicolumn{6}{|c|}{ Target 2: Halve, between 1990 and 2015, the proportion of people who suffer from hunger } \\
\hline Income share held by lowest $20 \%$ & $\ldots$ & 5 & $\ldots$ & $\ldots$ & $\ldots$ \\
\hline Poverty headcount, national (\% of population) & $\ldots$ & 38 & $\ldots$ & $\ldots$ & $\ldots$ \\
\hline Prevalence of underweight in children (under five years of age) & $\ldots$ & $\ldots$ & $\ldots$ & 13 & $\ldots$ \\
\hline \multicolumn{6}{|l|}{ Goal 2: Achieve universal primary education } \\
\hline \multicolumn{6}{|c|}{ Target 3: Ensure that, by 2015 , children everywhere, boys and girls alike, will be able to complete a full course of primary schooling } \\
\hline Primary completion rate, total (\% of relevant age group) & 51 & 52 & 56 & 54 & $\ldots$ \\
\hline Persistence to grade 5 , total (\% of cohort) & 69 & $\ldots$ & 51 & $\ldots$ & $\ldots$ \\
\hline Youth literacy rate $(\%$ ages $15-24)$ & 69 & $\ldots$ & $\ldots$ & 67 & $\ldots$ \\
\hline \multicolumn{6}{|l|}{ Goal 3: Promote gender equality and empower women } \\
\hline \multicolumn{6}{|c|}{ Target 4: Eliminate gender disparity in primary and secondary education preferably by 2005 and in all levels of education no later than 2015} \\
\hline Proportion of seats held by women in national parliament (\%) & 0 & 0 & 2 & 1 & 1 \\
\hline Ratio of girls to boys in primary and secondary education (\%) & 80 & $\ldots$ & 87 & 87 & $\ldots$ \\
\hline Ratio of young literate females to males (\% ages $15-24$ ) & 84 & & & 93 & $\ldots$ \\
\hline Share of women employed in the nonagricultural sector (\%) & 20 & 25 & 32 & 35 & $\ldots$ \\
\hline \multicolumn{6}{|l|}{ Goal 4: Reduce child mortality } \\
\hline \multicolumn{6}{|c|}{ Target 5: Reduce by two-thirds, between 1990 and 2015 , the under-five mortality rate } \\
\hline Immunization, measles (\% of children ages $12-23$ months) & 67 & 42 & 62 & 60 & 65 \\
\hline Infant mortality rate (per 1,000 live births) & 69 & 64 & 60 & 55 & 54 \\
\hline Under 5 mortality rate (per 1,000$)$ & 94 & 87 & 80 & 74 & 73 \\
\hline \multicolumn{6}{|l|}{ Goal 5: Improve maternal health } \\
\hline \multicolumn{6}{|c|}{ Target 6: Reduce by three-quarters, between 1990 and 2015 , the maternal mortality ratio } \\
\hline Births attended by skilled health staff (\% of total) & $\ldots$ & 53 & 41 & $\ldots$ & \\
\hline Maternal mortality ratio (modeled estimate, per 100,000 live births) & $\ldots$ & $\ldots$ & 300 & $\ldots$ & 470 \\
\hline \multicolumn{6}{|l|}{ Goal 6: Combat HIVIAIDS, malaria, and other diseases } \\
\hline \multicolumn{6}{|l|}{ Target 7: Have halted by 2015 and begun to reverse the spread of HIVIAIDS } \\
\hline Prevalence of HIV, total (\% of population aged $15-49)$ & $\ldots$ & $\ldots$ & 0.3 & 2.0 & 1.5 \\
\hline \multicolumn{6}{|c|}{ Target 8: Have halted by 2015 and begun to reverse the incidence of malaria and other major diseases } \\
\hline Contraceptive prevalence rate (\% of women ages $15-49$ ) & $\ldots$ & 26 & $\ldots$ & $\ldots$ & \\
\hline Incidence of tuberculosis (per 100,000 people) & 267 & 250 & 250 & 250 & 250 \\
\hline Tuberculosis cases detected under DOTS (\%) & $\ldots$ & 1 & 7 & 21 & 21 \\
\hline \multicolumn{6}{|l|}{ Goal 7: Ensure environmental sustainability } \\
\hline \multicolumn{6}{|c|}{ Target 9: Integrate the principles of sustainable development into country policies and program and reverse the loss of environmental resources } \\
\hline Forest area (\% of total land area) & 70 & $\ldots$ & 67 & 65 & 65 \\
\hline Nationally protected areas (\% of total land area) & $\ldots$ & $\ldots$ & $\ldots$ & 2 & $\ldots$ \\
\hline \multicolumn{6}{|c|}{ Target 10: Halve, by 2015 , the proportion of people without sustainable access to safe drinking water and basic sanitation } \\
\hline Access to an improved water source (\% of population) & 39 & 39 & 39 & 39 & 40 \\
\hline \multicolumn{6}{|c|}{ Target 11: Have achieved, by 2020 , a significant improvement in the lives of at least 100 million slum dwellers } \\
\hline Access to improved sanitation (\% of population) & 44 & 44 & 44 & 44 & 45 \\
\hline $\mathrm{CO} 2$ emissions (metric tons per capita) & 0.6 & 0.5 & 0.5 & 0.4 & $\ldots$ \\
\hline \multicolumn{6}{|l|}{ Goal 8: Develop a global partnership for development } \\
\hline \multicolumn{6}{|l|}{ Target 12: Various } \\
\hline Aid per capita (current US\$) & 100 & 79 & 51 & 45 & 45 \\
\hline Debt service (\% of exports) & 18 & 10 & 8 & 6 & 6 \\
\hline Fixed line and mobile phone subscribers (per 1,000 people) & 7 & 9 & 14 & 15 & $\ldots$ \\
\hline Internet users (per 1,000 people) & 0 & 0 & 8 & 23 & $\ldots$ \\
\hline Personal computers (per 1,000 people) & $\ldots$ & $\ldots$ & 53 & 64 & $\ldots$ \\
\hline
\end{tabular}

Source: World Development Indicators database, September 2008.

\section{CInternational Monetary Fund. Not for Redistribution}


Table 8. Papua New Guinea: Authorities' Response to Recent Fund Policy Advice 1/

Fund Recommendations

\begin{abstract}
Monetary and Exchange Rate Policy: Stand ready to tighten monetary policy given the expectation of a looser fiscal stance.

The exchange rate should be allowed to move flexibly as needed, should upward pressure be sustained or downward pressure unexpectedly materialize.
\end{abstract}

Fiscal Policy: A new proposal to update the medium term fiscal strategy (MTFS) should be approved to replace the current policy under the existing MTFS.

Containing the actual cash expenditure to more sustainable and stable levels, while ensuring that windfall revenue is used for well-designed MTDSprioritized spending and debt reduction.

Proposals to increase public borrowing to fund largescale investment projects are a concern.

The resumption of public sector reform plans is urgently needed to help improve implementation capacity, and strengthen monitoring, accountability, and transparency.

Financial Sector Policy: Need to overcome the underlying structural rigidities that are constraining development, including weak enforcement of contracts and creditor rights.

The revived development bank should not engage in expensive borrowing and expansion into microfinance should comply with due diligence and commercial criteria.

\section{Policy Actions}

The policy interest was increased during the second half of year 2008. To better control liquidity part of the funds in trust accounts held at private banks has been transferred to the BPNG

Exchange rate daily volatility has increased since 2007. However, reserves have been drawn down to resist depreciation pressures in kina-U.S. dollar cross rate.

The new MTFS was approved in July 2008.

Windfall revenue has been partly used to early repayment of debt. However, spending at the provincial and district level has been allocated outside the MTDS priority areas.

Public borrowing has increased to fund the LNG project.

Progress has been limited and it appears to lack political will.

Progress has been slow, although some actions have been made on improving credit monitoring, including the establishment of the credit and data bureau that provides data to inform credit decisions. The authorities have requested an FSAP that is tentatively scheduled for the fall of 2009.

The development bank has remained very small and profitable.

\footnotetext{
Structural Reforms: Broader reforms are necessary to lift medium-term growth by boosting productivity, and to strengthen international competitiveness and resilience to external shocks.

Intensive efforts to improve macroeconomic statistics to address shortcomings in the quality, coverage and timeliness of macroeconomic data.

Progress has been disappointing.

Limited progress has been made in improving the quality of macroeconomic data, with the exception of the bop data where progress has been substantial.
}

Source: IMF Staff.

1/ Advice from the 2007 Article IV Consultation. 


\section{Appendix I: Papua New Guinea: DebT Sustainability Analysis}

\section{INTRODUCTION}

\section{Papua New Guinea has made significant progress in reducing its public debt burden.} However, Papua New Guinea still remains at moderate risk of external debt distress over the medium and long term. External debt burden indicators on public and publicly guaranteed (PPG) external debt are below their indicative thresholds under the baseline scenario, but some indicators would breach their thresholds if the terms of trade deteriorates further or LNG project related contingent liabilities are materialized. ${ }^{1}$ Compared to the 2007 Article IV DSA, given the change in the global outlook, this analysis shows that Papua New Guinea exhibits more vulnerability to external shocks. The inclusion of domestic debt as well as several contingent liabilities also shows risks to long-run fiscal sustainability. Box 1 summarizes the macroeconomic framework underlying the baseline analysis.

\section{Public Debt Sustainability Analysis ${ }^{2}$}

The public sector debt has been declining over the past 7 years (Table 1) from about $71 \frac{1}{2}$ percent in 2002 to under 34 percent of GDP in 2007. This improvement reflects prudent fiscal policy, favorable terms of trade, appreciation of the kina against the U.S. dollar, lower interest rates, and sustained economic growth since 2003. The public external debt also declined from the peak of over 50 percent of GDP in 2001 to below 17 percent at end-2007. ${ }^{3}$ External debt to multilateral institutions accounts for about 65 percent of public external debt, with Japan as the main bilateral creditor. Private sector external debt is estimated at about 14 percent of GDP at end-2007.

\section{The baseline scenario envisages a gradual increase in the public debt-to-GDP ratio in} the medium term. ${ }^{4}$ It reflects the additional financing needs on the external side, mainly due to the sharp deterioration of the terms of trade and corresponding current account. However, all debt burden indicators remain well below the thresholds and are expected to decline in the long run. On the domestic side, the expectation of continued prudent fiscal policy and

\footnotetext{
${ }^{1}$ Papua New Guinea is rated as a weak performer for its policies and institutions for the purposes of the IMFWB low-income country DSA framework. Consequently, the applicable thresholds for this category to external public debt are: 30 percent for the present value (PV) of debt-to-GDP ratio; 100 percent for the PV of debt-toexports ratio, 200 percent for the PV of debt-to-revenue ratio, 15 percent for the debt service-to-exports ratio, and 25 percent for the debt service-to-revenue ratio.

${ }^{2}$ Public debt includes domestic central government debt and external public and publicly guaranteed debt.

${ }^{3}$ By end-2008, it is estimated that public debt declined further to about $26 \frac{1}{2}$ percent of GDP with public external debt about 12 percent.

${ }^{4}$ Baseline scenario does not include the LNG project.
} 
favorable debt dynamics are expected to help the public domestic debt burden continue to decline in the medium and long term. In sum, the public debt-to-GDP ratio is projected to peak at 30 percent in the medium term, then gradually decline to $22 \frac{1}{2}$ percent in the long run.

\section{The standard alternative scenarios and bound tests indicate that the projected debt} path is particularly sensitive to changes in real GDP growth and further deterioration of terms of trade (Table 2 and Figure 2). A shock to real GDP growth during 2009-10, equal to the historical average of GDP growth rate minus one standard deviation, would bring the present value (PV) of the public debt-to-GDP ratio to 71 percent in 2028. This highlights the need to manage expenditures prudently, while protecting priority spending, in the event of a growth slowdown. Further deterioration of the terms of trade would also bring the public debt burden to the alarming level, as discussed more detail below.

\section{Fiscal sustainability is sensitive to other liabilities arising from several sources. ${ }^{5}$ Unfunded civil service liabilities, amounting to be about 11 percent of GDP at end-2008, will remain sizeable though the government has made partial repayment recently. LNG project related contingent liabilities are estimated to be, in PV term, about $20 \frac{1}{2}$ percent of GDP in $2013 .^{6}$}

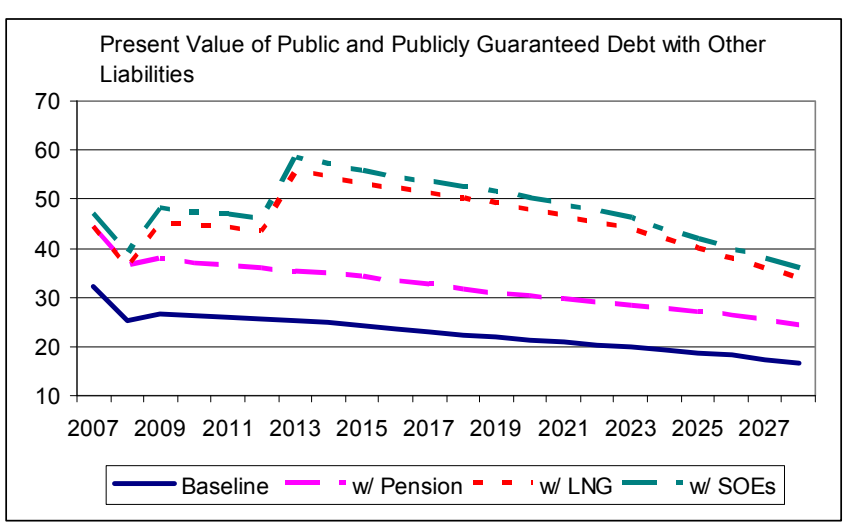

Borrowings by SOEs are also estimated to be significant and growing, although information is limited. ${ }^{7}$ Other contingent liabilities arising from the government's commitments under the memorandum of agreement with landowners are also reported to be significant and the government needs to pay some liabilities in near future to allow the LNG project to move forward.

\footnotetext{
${ }^{5}$ Only unfunded pension liabilities are included in Table 1 since other liabilities are all Fund staff estimates.

${ }^{6}$ These liabilities are arising from the issue of exchangeable bonds to finance the state's equity participation (in 2009) and the state's completion guarantee for debt financing (by 2013). Under this scheme, the creditor acquires exchangeable bonds, amounting to US\$1.1 billion, with the option to exchange the bonds for equities in the Oil Search company. If the share price remains below this strike price, the state will have to pay to the creditor the difference between the market price and the face value of the bond. Under the completion guarantee, if the project fails, the government will have to pay up to US\$2 billion to the creditor.

${ }^{7}$ Preliminary estimates for SOE related contingent liabilities, based on end-2007 financial statements of nine SOEs, are about 2.5 percent of GDP when we consider borrowings, various provisions, and other liabilities. However, there is no information on the off-balance sheet liabilities which also may be significant.
} 


\section{External Debt Sustainability Analysis}

\section{All PPG external debt and debt service indicators remain below the policy-dependent} debt burden thresholds under the baseline scenario. However, a country-specific scenario indicates the vulnerability of the external debt sustainability if the terms of trade deteriorates further in the medium term. The main results of the external DSA are as follows:

- The debt burden indicators in the baseline scenario are expected to increase in the medium term before declining in the long run (Table 3 ). Additional financing needs arising from the deterioration of the terms of trade and corresponding current account would raise the PV of PPG external debt over GDP from below 11 percent in 2008 to 12 percent in the medium term, which is still well below the 30 percent of threshold. The PVs of PPG external debt-to-exports and debt-to-revenue ratios are also expected to increase accordingly in the medium term, but still well below the indicative threshold levels.

- The debt burden is expected to increase under the various standard stress tests, but all debt burden indicators remain below their indicative thresholds (Table 4 and Figure 1). Alternative scenarios with key variables at their historical averages in 2008-28 show a reduction of the debt burden because of the current account surpluses and FDI inflows in recent commodity booming years. ${ }^{8}$

- A country-specific scenario shows that the external debt sustainability would be vulnerable to the terms of trade shock. If export prices decline further, by 20 percent compared to the January 2009 WEO price assumption for 2009-13, the PV of external PPG debt-to-GDP ratio is projected to breach the 30 percent threshold in the medium term, due to the deterioration of current account and corresponding additional

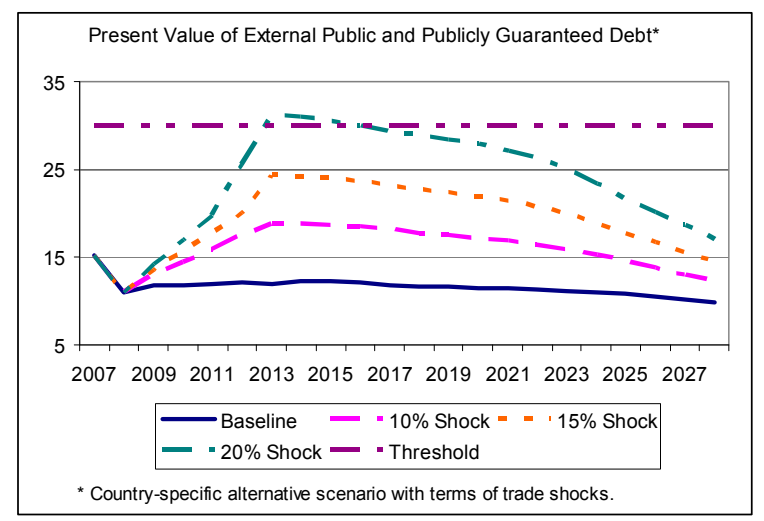

\footnotetext{
${ }^{8}$ Bound test B5, which combines four different shocks with smaller standard deviations than those shocks in tests B1-B4, also shows the similar patterns because recent rapid growth in exports during the commodity booming period generates rather improvement in the current account under this test.
} 
financing needs. ${ }^{9}$ The other debt and debt service indicators would rise significantly for the same period, though they are not expected to breach their indicative thresholds.

\section{Box 1. Macroeconomic Assumptions Underlying the DSA}

- Real GDP growth is projected to be at around 3.8 percent in the near term and then slow to about $2 \frac{1}{2}$ percent in the medium and long term - above the recent historical average of 2 percent. Moderate growth in the nonmineral sector, including in agriculture, and the several mining projects coming on stream will offset a steady decline in petroleum and copper production. However, the large Liquefied Natural Gas (LNG) project under consideration is not incorporated in the baseline scenario.

- Inflation is projected to peak in 2008 because of the rise in food and energy prices until July, and subsequently stabilize at around 2 percent in the long run.

- The current account surplus (including grants) will turn into a deficit in the near and medium term, primarily reflecting continued strong growth of capital imports related to investment projects as well as the impact of global economic slowdown.

- The grant element of loans is expected to decline. As per capita income rises, the share of external financing provided on concessional terms is expected to decline gradually over the projection period. ${ }^{1}$

- The fiscal balance is projected to turn into a deficit in 2009 and to remain in deficit over the medium term, due to falling mineral revenues and the spending of preceding years' mineral windfall revenues. The deficit is expected to be financed by a run down of resources held in trust accounts.

${ }^{1}$ Grant element of new public borrowing increases slightly in the near term, before it declines in the long run, due to the relatively large disbursement commitment from the AsDB in the pipeline.

The following text table summarizes Papua New Guinea's indicative thresholds, actual 2007 ratios, and average debt ratio dynamics in the medium and long term under the baseline scenario.

\footnotetext{
${ }^{9}$ Considering that PNG currently has comfortable level of reserves, we assume that additional financing needs would be filled by additional concessional external borrowings and the use of reserves. However, if the import coverage of reserves falls below 3 months, we assume that all financing needs should be filled by additional external borrowings.
} 
Text Table: Policy-based PPG External Debt Burden Thresholds for PNG

\begin{tabular}{lcccc}
\hline & Thresholds & PNG's ratios \\
& & 2007 & 2008-13 & 2014-28 \\
\hline PV of debt in percent of & 30 & 15.2 & 11.8 & 11.3 \\
$\quad$ GDP & 100 & 19.2 & 19.3 & 22.6 \\
Exports & 200 & 45.4 & 48.6 & 43.3 \\
$\quad$ Revenues & 15 & 4.1 & 2.1 & 1.6 \\
Debt service in percent of & 25 & 9.7 & 5.2 & 3.2 \\
$\quad$ Exports & & & \\
Revenues & & &
\end{tabular}

\section{Conclusion}

\section{Papua New Guinea still remains at moderate risk of external debt distress over the medium term. Though external PPG debt burden indicators are well below their indicative thresholds under the baseline scenario, the projected PPG debt paths point to a significant vulnerability against the terms of trade shock and slower economic growth. The inclusion of the liabilities arising from several sources raises concerns about long-term fiscal sustainability.}

Continued prudent management of debt over the medium and long term will be required to mitigate the risks to public debt sustainability. The staff encourages the authorities to build on recent steps and move forward to strengthen debt management capacity. 
Table 1. Papua New Guinea: Public Sector Debt Sustainability Framework, Baseline Scenario, 2005-28

(In percent of GDP, unless otherwise indicated)

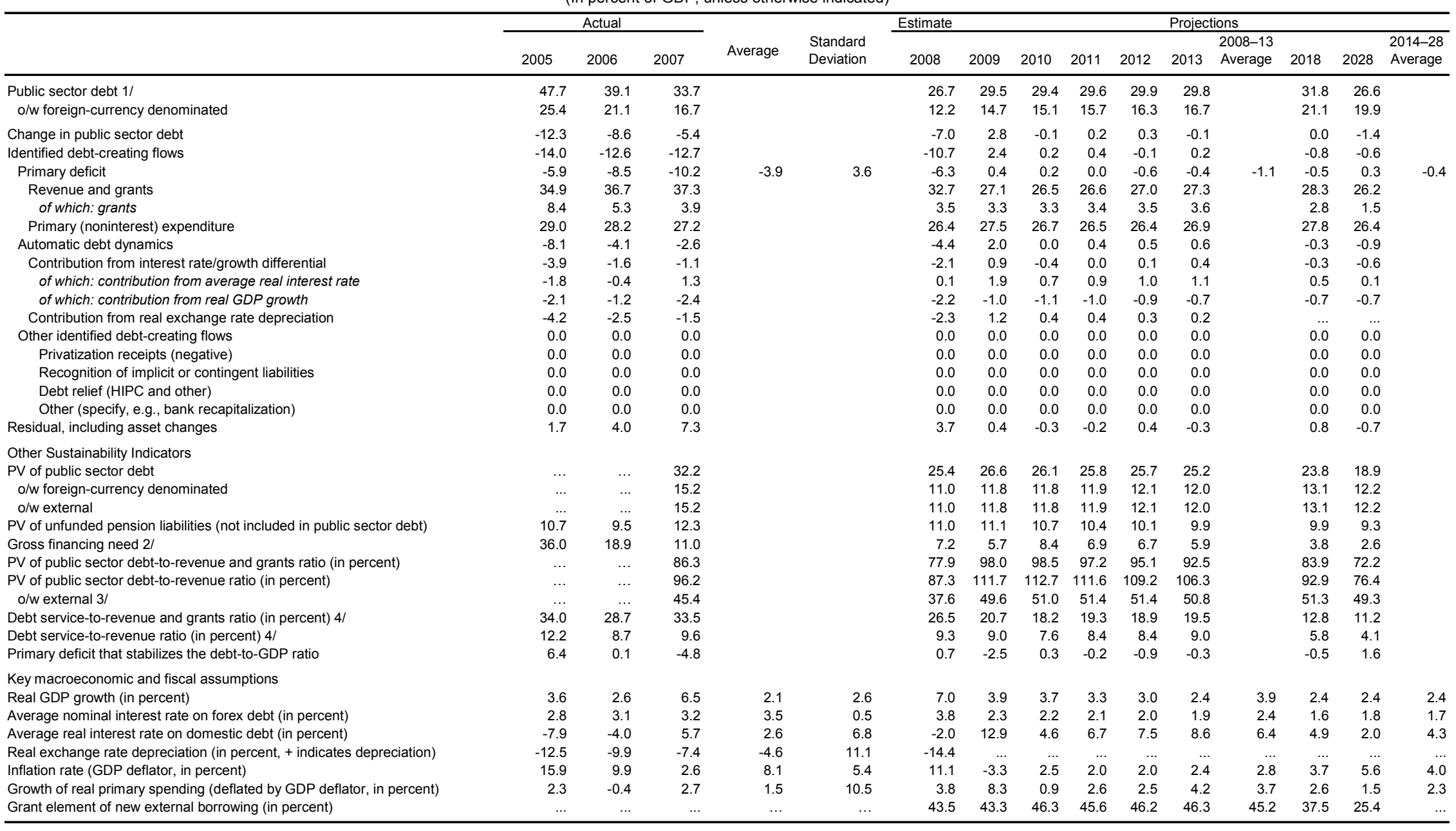

Sources: Country authorities; and Fund staff estimates and projections.

1/ Public debt includes gross debt of central government, central bank, and statutory authorities.

2/ Gross financing need is defined as the primary deficit plus debt service plus the stock of short-term debt at the end of the last period.

$3 /$ Revenues excluding grants.

I 


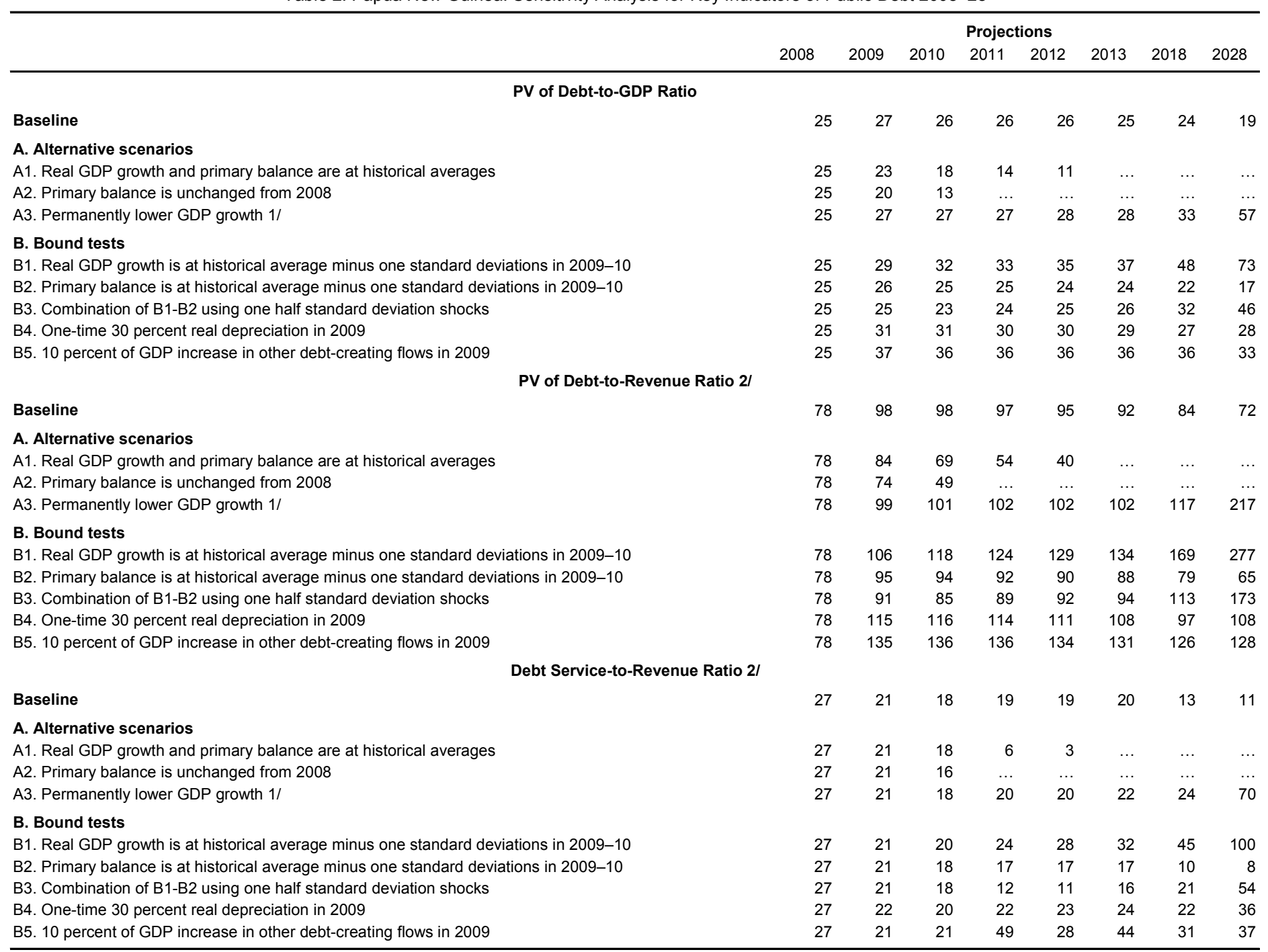

Sources: Country authorities; and Fund staff estimates and projections.

1/ Assumes that real GDP growth is at baseline minus one standard deviation divided by the length of the projection period.

2/ Revenues are defined inclusive of grants. 
Table 3. Papua New Guinea: External Debt Sustainability Framework, Baseline Scenario, 2005-28 1/

(In percent of GDP, unless otherwise indicated)

\begin{tabular}{|c|c|c|c|c|c|c|c|c|c|c|c|c|c|c|c|}
\hline & \multicolumn{3}{|c|}{ Actual } & \multirow{2}{*}{$\begin{array}{l}\text { Historical } \\
\text { Average }\end{array}$} & \multirow{2}{*}{$\begin{array}{l}\text { Standard } \\
\text { Deviation }\end{array}$} & \multicolumn{6}{|c|}{ Projections } & \multirow[b]{2}{*}{$\begin{array}{l}2008-13 \\
\text { Average }\end{array}$} & \multirow[b]{2}{*}{2018} & \multirow[b]{2}{*}{2028} & \multirow[b]{2}{*}{$\begin{array}{l}\text { 2014-28 } \\
\text { Average }\end{array}$} \\
\hline & 2005 & 2006 & 2007 & & & 2008 & 2009 & 2010 & 2011 & 2012 & 2013 & & & & \\
\hline External debt (nominal) $1 /$ & 41.2 & 38.6 & 30.7 & & & 24.4 & 27.9 & 29.5 & 31.2 & 33.2 & 34.7 & & 37.8 & 35.0 & \\
\hline $\mathrm{o} / \mathrm{w}$ public and publicly guaranteed (PPG) & 25.4 & 21.1 & 16.7 & & & 12.2 & 14.7 & 15.1 & 15.7 & 16.3 & 16.7 & & 21.1 & 19.9 & \\
\hline Change in external debt & -10.6 & -2.6 & -7.9 & & & -6.3 & 3.5 & 1.5 & 1.7 & 2.0 & 1.5 & & 0.3 & -1.1 & \\
\hline Identified net debt-creating flows & -14.2 & -10.4 & $\begin{array}{r}-12.2 \\
-4.0\end{array}$ & -60 & 29 & $\begin{array}{r}-7.9 \\
-4.7\end{array}$ & $\begin{array}{r}2.5 \\
4.9\end{array}$ & 0.4 & 0.0 & -0.5 & $\begin{array}{l}-1.2 \\
0.8\end{array}$ & & $\begin{array}{l}-3.1 \\
-2.4\end{array}$ & $\begin{array}{r}-1.4 \\
-1.5\end{array}$ & -18 \\
\hline Deficit in balance of goods and services & $\begin{array}{l}-3.5 \\
-2.9\end{array}$ & $\begin{array}{l}-4.9 \\
-9.3\end{array}$ & $\begin{array}{l}-4.0 \\
-5.7\end{array}$ & & & $\begin{array}{l}-4.7 \\
-6.0\end{array}$ & $\begin{array}{l}4.9 \\
4.8\end{array}$ & 2.8 & 2.5 & $\begin{array}{l}1.8 \\
2.1\end{array}$ & $\begin{array}{l}0.6 \\
1.3\end{array}$ & & $\begin{array}{c}-2.4 \\
-11.9\end{array}$ & $\begin{array}{l}-1.5 \\
-8.5\end{array}$ & -1.8 \\
\hline Exports & 71.7 & 79.9 & $\begin{aligned}-0.1 \\
79.1\end{aligned}$ & & & $\begin{array}{r}-0.0 \\
70.6\end{array}$ & 54.9 & 58.9 & 60.7 & 61.5 & 61.6 & & 53.4 & 38.8 & \\
\hline Imports & 68.8 & 70.6 & 73.5 & & & 64.5 & 59.7 & 61.8 & 63.2 & 63.5 & 62.9 & & 41.5 & 30.3 & \\
\hline Net current transfers $($ negative $=$ inflow $)$ & -8.9 & -4.9 & -5.5 & -5.8 & 1.3 & -3.9 & -3.7 & -3.8 & -3.9 & -4.0 & -4.1 & & -3.2 & -1.8 & 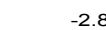 \\
\hline o/w official & $\begin{array}{l}-0.9 \\
-8.0\end{array}$ & -5.3 & -4.9 & & & $\begin{array}{l}-3.9 \\
-3.5\end{array}$ & -3.3 & $\begin{array}{l}-3.0 \\
-3.3\end{array}$ & $\begin{array}{l}-3.5 \\
-3.4\end{array}$ & $\begin{array}{l}-4.0 \\
-3.5\end{array}$ & $\begin{array}{l}-4.1 \\
-3.6\end{array}$ & & -2.8 & -1.6 & \\
\hline Other current account flows (negative = net inflow) & $\begin{array}{r}-0.0 \\
6.3\end{array}$ & 9.3 & $\begin{array}{r}-4.9 \\
7.1\end{array}$ & & & 5.3 & $\begin{array}{r}-3.0 \\
3.8\end{array}$ & 3.8 & $\begin{array}{r}-5.4 \\
3.7\end{array}$ & $\begin{array}{r}-3.5 \\
3.7\end{array}$ & 3.6 & & 12.7 & 8.7 & \\
\hline Net FDI (negative = inflow) & $\begin{array}{r}6.3 \\
-1.4\end{array}$ & $\begin{array}{r}-3.3 \\
-3.4\end{array}$ & $\begin{array}{r}-.1 \\
-7.2\end{array}$ & -3.4 & 2.7 & $\begin{array}{r}5.3 \\
-3.4\end{array}$ & $\begin{array}{r}-3.8 \\
-3.2\end{array}$ & $\begin{array}{l}3.8 \\
-3.3\end{array}$ & $\begin{array}{r}3.1 \\
-3.4\end{array}$ & -3.5 & $\begin{array}{r}3.6 \\
-3.6\end{array}$ & & -2.1 & -1.2 & -1.9 \\
\hline Endogenous debt dynamics 2 I & $\begin{array}{l}-1.4 \\
-7.4\end{array}$ & $\begin{array}{l}-3.4 \\
-2.0\end{array}$ & $\begin{array}{l}-1.2 \\
-0.9\end{array}$ & -3.4 & 2.8 & $\begin{array}{r}-3.4 \\
0.1\end{array}$ & $\begin{array}{r}-3.8 \\
0.8\end{array}$ & 0.9 & $\begin{array}{r}-3.4 \\
1.0\end{array}$ & $\begin{array}{r}-3.5 \\
1.2\end{array}$ & $\begin{array}{r}-3.6 \\
1.5\end{array}$ & & $\begin{array}{r}-2.1 \\
1.4\end{array}$ & $\begin{array}{r}-1.2 \\
1.4\end{array}$ & -1.5 \\
\hline Contribution from nominal interest rate & 1.3 & 2.6 & 2.3 & & & 1.9 & 1.7 & 1.8 & 2.0 & 2.1 & 2.3 & & 2.2 & 2.2 & \\
\hline Contribution from real GDP growth & -1.6 & $\begin{array}{r}2.0 \\
-0.9\end{array}$ & -2.3 & & & -1.8 & -1.0 & -1.0 & -0.9 & -0.9 & -0.8 & & -0.8 & -0.8 & \\
\hline Contribution from price and exchange rate changes & $\begin{array}{l}-1.0 \\
-7.1\end{array}$ & -3.7 & -1.0 & & & -1.8 & -1.0 & -1.0 & -0.9 & -0.9 & -0.8 & & -0.8 & -0.8 & \\
\hline Residual (3-4) 3/ & 3.6 & 7.8 & 4.2 & & & 1.6 & 1.0 & 1.2 & 1.8 & 2.4 & 2.8 & & 3.4 & 0.3 & \\
\hline o/w exceptional financing & 0.0 & 0.0 & 0.0 & & & 0.0 & 0.0 & 0.0 & 0.0 & 0.0 & 0.0 & & 0.0 & 0.0 & \\
\hline PV of external debt $4 /$ & $\ldots$ & $\ldots$ & 29.2 & & & 23.1 & 25.0 & 26.2 & 27.4 & 28.9 & 30.1 & & 29.8 & 27.3 & \\
\hline In percent of exports & $\ldots$ & $\ldots$ & 36.9 & & & 32.8 & 45.5 & 44.4 & 45.2 & 47.0 & 48.8 & & 55.7 & 70.4 & \\
\hline PV of PPG external debt & $\ldots$ & $\ldots$ & 15.2 & & & 11.0 & 11.8 & 11.8 & 11.9 & 12.1 & 12.0 & & 13.1 & 12.2 & \\
\hline In percent of exports & $\ldots$ & $\ldots$ & 19.2 & & & 15.5 & 21.5 & 20.1 & 19.6 & 19.7 & 19.5 & & 24.5 & 31.4 & \\
\hline In percent of government revenues & & & 45.4 & & & 37.6 & 49.6 & 51.0 & 51.4 & 51.4 & 50.8 & & 51.3 & 49.3 & \\
\hline Debt service-to-exports ratio (in percent) & 9.7 & 8.3 & 8.4 & & & 6.4 & 7.4 & 7.3 & 7.3 & 7.3 & 8.7 & & 9.7 & 13.3 & \\
\hline PPG debt service-to-exports ratio (in percent) & 6.0 & 3.5 & 4.1 & & & 2.5 & 2.1 & 2.1 & 2.0 & 1.9 & 1.9 & & 1.7 & 2.6 & \\
\hline PPG debt service-to-revenue ratio (in percent) & 16.4 & 9.0 & 9.7 & & & 6.0 & 4.9 & 5.3 & 5.3 & 5.0 & $\mathbf{5 . 0}$ & & 3.5 & 4.0 & \\
\hline Total gross financing need (Billions of U.S. dollars) & 0.0 & -0.1 & -0.3 & & & -0.3 & 0.5 & 0.3 & 0.3 & 0.2 & 0.2 & & 0.1 & 0.5 & \\
\hline Non-interest current account deficit that stabilizes debt ratio & 5.2 & -2.3 & 3.9 & & & 1.6 & 1.4 & 1.3 & 0.6 & -0.2 & -0.7 & & -2.7 & -0.4 & \\
\hline \multicolumn{16}{|l|}{ Key macroeconomic assumptions } \\
\hline Real GDP growth (in percent) & 3.6 & 2.6 & 6.5 & 1.4 & 3.5 & 7.0 & 3.9 & 3.7 & 3.3 & 3.0 & 2.4 & 3.9 & 2.4 & 2.4 & 2.4 \\
\hline GDP deflator in U.S. dollar terms (change in percent) & 15.9 & 9.9 & 2.6 & 8.4 & 5.2 & 11.1 & -3.3 & 2.5 & 2.0 & 2.0 & 2.4 & 2.8 & 3.7 & 5.6 & 4.0 \\
\hline Effective interest rate (percent) $5 /$ & 3.0 & 7.2 & 6.6 & 4.5 & 1.4 & 7.5 & 7.1 & 7.0 & 7.0 & 7.1 & 7.1 & 7.1 & 6.3 & 6.5 & 6.4 \\
\hline Growth of exports of G\&S (U.S. dollar terms, in percent) & 27.3 & 27.6 & 12.9 & 6.5 & 18.7 & 13.0 & -21.1 & 9.8 & 5.5 & 3.8 & 3.2 & 2.4 & 3.6 & 29 & $\begin{array}{ll}0.4 \\
3.0\end{array}$ \\
\hline Growth of imports of G\&S (U.S. dollar terms, in percent) & 35.6 & 17.5 & 18.5 & 9.4 & 20.5 & 11.3 & -6.2 & 5.8 & 4.8 & $\begin{array}{l}3.0 \\
3.1\end{array}$ & $\begin{array}{l}0.2 \\
1.9\end{array}$ & 3.5 & $\begin{array}{l}0.0 \\
2.9\end{array}$ & 3.0 & 1.3 \\
\hline Grant element of new public sector borrowing (in percent) & & & & & & 43.5 & 43.3 & 46.3 & 45.6 & 46.2 & 46.3 & 45.2 & 37.5 & 25.4 & 33.8 \\
\hline Government revenues (excluding grants, in percent of GDP) & 26.5 & 31.4 & 33.5 & & & 29.1 & 23.8 & 23.2 & 23.2 & 23.5 & 23.7 & & 25.6 & 24.7 & 25.5 \\
\hline Aid flows (in Billions of U.S. dollars) 71 & 0.5 & 0.3 & 0.3 & & & 0.3 & 0.5 & 0.4 & 0.4 & 0.5 & 0.5 & & 0.5 & 0.4 & \\
\hline o/w Grants & 0.4 & 0.3 & 0.2 & & & 0.3 & 0.3 & 0.3 & 0.3 & 0.3 & 0.3 & & 0.3 & 0.3 & \\
\hline o/w Concessional loans & 0.0 & 0.0 & 0.0 & & & 0.0 & 0.2 & 0.1 & 0.2 & 0.2 & 0.1 & & 0.2 & 0.1 & \\
\hline Grant-equivalent financing (in percent of GDP) 8 / & 0.0 & & & & & 3.6 & 4.5 & 4.2 & 4.3 & 4.4 & 4.3 & & 3.4 & 1.7 & 2.9 \\
\hline Grant-equivalent financing (in percent of external financing) $8 /$ & $\cdots$ & $\cdots$ & $\ldots$ & & & 96.7 & 73.8 & 81.6 & 81.0 & 80.4 & 82.6 & & 75.3 & 71.2 & 73.8 \\
\hline \multirow{3}{*}{$\begin{array}{l}\text { Memorandum items: } \\
\text { Nominal GDP (Billions of U.S. dollars) } \\
\text { Nominal dollar GDP growth }\end{array}$} & & & & & & & & & & & & & & & \\
\hline & 4.9 & 5.6 & 6.4 & & & 8.1 & 8.2 & 8.4 & 8.6 & 8.8 & 9.1 & & 12.3 & 22.5 & \\
\hline & 24.7 & 14.4 & 13.9 & & & 26.7 & 1.3 & 2.3 & 2.4 & 2.6 & 2.9 & 6.4 & 6.2 & 6.2 & 6.2 \\
\hline
\end{tabular}

Source: Staff simulations

1/ Includes both public and private sector external debt.

Deriod debt ratio, with $\mathrm{i}=$ nominal interest rate; $\mathrm{g}=$ real GDP growth rate, and $\mathrm{r}=$ growth rate of GDP deflator in $\mathrm{U} S$. dollar terms.

3/ Includes exceptional financing (i.e., changes in arrears and debt relief); $c$ is

$5 /$ Assumes that PV of private sector debt is equivalent to its face value.

6/ Historical averages and standard deviations are generally derived over the past 10 years, subject to data availability.

8/ Grant-equivalent financing includes grants provided directly to the government and through new borrowing (difference between the face value and the PV of new debt).

\section{CInternational Monetary Fund. Not for Redistribution}


Table 4a. Papua New Guinea: Sensitivity Analysis for Key Indicators of Public and Publicly Guaranteed External Debt, 2008-28 (In percent)

\begin{tabular}{|c|c|c|c|c|c|c|c|c|}
\hline & & & & Projecti & & & & \\
\hline & 2008 & 2009 & 2010 & 2011 & 2012 & 2013 & 2018 & 2028 \\
\hline PV of debt-to GDP & & & & & & & & \\
\hline Baseline & 11 & 12 & 12 & 12 & 12 & 12 & 13 & 12 \\
\hline A. Alternative Scenarios & & & & & & & & \\
\hline A1. Key variables at their historical averages in 2008-28 1/ & 11 & 4 & & & & & & \\
\hline A2. New public sector loans on less favorable terms in 2008-28 21 & 11 & 12 & 12 & 11 & 11 & 11 & 11 & 8 \\
\hline A3. Deterioration of the terms of trade in 2009-13 3/ & 11 & 14 & 17 & 20 & 26 & 31 & 29 & 19 \\
\hline B. Bound Tests & & & & & & & & \\
\hline B1. Real GDP growth at historical average minus one standard deviation in 2009-10 & 11 & 12 & 13 & 13 & 14 & 14 & 15 & 12 \\
\hline B2. Export value growth at historical average minus one standard deviation in 2009-10 4/ & 11 & 6 & 10 & 11 & 11 & 11 & 12 & 11 \\
\hline B3. U.S. dollar GDP deflator at historical average minus one standard deviation in 2009-10 & 11 & 11 & 11 & 12 & 12 & 12 & 13 & 10 \\
\hline B4. Net non-debt creating flows at historical average minus one standard deviation in 2009-10 5/ & 11 & 13 & 14 & 15 & 15 & 15 & 15 & \\
\hline B5. Combination of B1-B4 using one-half standard deviation shocks & 11 & & & & & & & \\
\hline B6. One-time 30 percent nominal depreciation relative to the baseline in $20096 /$ & 11 & 17 & 17 & 18 & 18 & 18 & 19 & 16 \\
\hline $\mathrm{PV}$ of debt-to-export & & & & & & & & \\
\hline Baseline & 16 & 22 & 20 & 20 & 20 & 20 & 25 & 31 \\
\hline A. Alternative Scenarios & & & & & & & & \\
\hline A1. Key variables at their historical averages in 2008-28 1/ & 16 & 7 & & & & & & \\
\hline A2. New public sector loans on less favorable terms in 2008-28 $2 /$ & 16 & 22 & 20 & 19 & 18 & 18 & 20 & 20 \\
\hline A3. Deterioration of the terms of trade in 2009-13 3/ & 16 & 32 & 36 & 41 & 53 & 64 & 56 & 47 \\
\hline B. Bound Tests & & & & & & & & \\
\hline B1. Real GDP growth at historical average minus one standard deviation in 2009-10 & 16 & 21 & 21 & 21 & 22 & 23 & 28 & 32 \\
\hline B2. Export value growth at historical average minus one standard deviz & 16 & 10 & 19 & 20 & 21 & 21 & 27 & 33 \\
\hline B3. U.S. dollar GDP deflator at historical average minus one standard deviation in 2009-10 & 16 & 21 & 21 & 21 & 22 & 23 & 28 & 32 \\
\hline B4. Net non-debt creating flows at historical average minus one standard deviation in 2009-10 5/ & 16 & 23 & 25 & 25 & 26 & 27 & 32 & 34 \\
\hline B5. Combination of B1-B4 using one-half standard deviation shocks & 16 & & & & & & & \\
\hline B6. One-time 30 percent nominal depreciation relative to the baseline in $20096 /$ & 16 & 21 & 21 & 21 & 22 & 23 & 28 & 32 \\
\hline PV of debt-to-revenu & & & & & & & & \\
\hline Baseline & 38 & 50 & 51 & 51 & 51 & 51 & 51 & 49 \\
\hline A. Alternative Scenarios & & & & & & & & \\
\hline A1. Key var & 38 & 16 & & & & & & \\
\hline A2. New public sector loans on less favorable terms in 2008-28 21 & 38 & 50 & 50 & 49 & 48 & 46 & 42 & 32 \\
\hline A3. Deterioration of the terms of trade in 2009-13 3/ & 35 & 49 & 62 & 75 & 99 & 120 & 110 & 70 \\
\hline B. Bound Tests & & & & & & & & \\
\hline B1. Real GDP gro & 38 & 52 & 56 & 58 & 58 & 58 & 57 & 48 \\
\hline B2. Export value growth at historical average minus one standard dev & 38 & 27 & 44 & 46 & 47 & 47 & 49 & 43 \\
\hline B3. U.S. dollar GDP deflator at historical average minus one standard deviation in 2009-10 & 38 & 47 & 49 & 50 & 51 & 51 & 49 & 41 \\
\hline B4. Net non-debt creating flows at historical average minus one standard deviation in 2009-10 5/ & 38 & 54 & 62 & 63 & 63 & 63 & 60 & 46 \\
\hline B5. Combination of B1-B4 using one-half standard deviation shocks & 38 & $\ldots$ & $\dddot{m}$ & & $\ldots$ & $\ldots$ & $\ldots$ & \\
\hline B6. One-time 30 percent nominal depreciation relative to the baseline in $20096 /$ & 38 & 72 & 75 & 77 & 78 & 78 & 76 & \\
\hline
\end{tabular}


Table 4b. Papua New Guinea: Sensitivity Analysis for Key Indicators of Public and Publicly Guaranteed External Debt, 2008-28 (continued)

(In percent)

\begin{tabular}{ccccccccc}
\hline & \multicolumn{10}{c}{ Projections } \\
\cline { 2 - 7 }
\end{tabular}

Debt service-to-exports ratio

\section{Baseline}

A. Alternative Scenarios

A1. Key variables at their historical averages in 2008-28 $1 /$

sector loans on less favorable terms in 2008-28 2

A3. Deterioration of the terms of trade in 2009-13

B. Bound Tests

B1. Real GDP growth at historical average minus one standard deviation in 2009-10

B2. Export value growth at historical average minus one standard deviation in 2009-10 4

B3. U.S. dollar GDP deflator at historical average minus one standard deviation in 2009-10

B4. Net non-debt creating flows at historical average minus one standard deviation in 2009-10

B5. Combination of B1-B4 using one-half standard deviation shocks

B6. One-time 30 percent nominal depreciation relative to the baseline in 20096

Debt service-to-revenue ratio

\section{Baseline}

\section{A. Alternative Scenarios}

A1. Key variables at their historical averages in 2008-28 1/

A2. New public sector loans on less favorable terms in 2008-28 2

A3. Deterioration of the terms of trade in 2009-13

\section{B. Bound Tests}

B1. Real GDP growth at historical average minus one standard deviation in 2009-10

B2. Export value growth at historical average minus one standard deviation in 2009-10 4/

B3. U. . dollar GDP deflator at historical average minus one standard deviation in 2009-10

B4. Net non-debt creating flows at historical average minus one standard deviation in 2009-10 $5 /$

B5. Combination of B1-B4 using one-half standard deviation shocks

B6. One-time 30 percent nominal depreciation relative to the baseline in 20096

Memorandum item:

Grant element assumed on residual financing (i.e., financing required above baseline) 71

$\begin{array}{rrrrrrrr}2 & 2 & 2 & 2 & 2 & 2 & 2 & 3 \\ & & & & & & & \\ 2 & 2 & \ldots & \ldots & \ldots & \ldots & \ldots & \ldots \\ 2 & 2 & 2 & 2 & 2 & 2 & \mathbf{2} & 1 \\ 2 & 3 & 3 & 3 & 3 & 3 & \mathbf{2} & 5 \\ & & & & & & & \\ & & & & & & & \\ 2 & 2 & 2 & 2 & 2 & 2 & 2 & 3 \\ 2 & 2 & 2 & 2 & 2 & 2 & 1 & 3 \\ 2 & 2 & 2 & 2 & 2 & 2 & 2 & 3 \\ 2 & 2 & 2 & 2 & 2 & 2 & 2 & 3 \\ 2 & \ldots & \ldots & \ldots & \ldots & \ldots & \ldots & \ldots \\ 2 & 2 & 2 & 2 & 2 & 2 & \mathbf{2} & 3\end{array}$

Source: Staff projections and simulations.

1 / Variables include real GDP growth, growth of GDP deflator (in U.S. dollar terms), non-interest current account in percent of GDP, and non-debt creating flows.

2/ Assumes that the interest rate on new borrowing is by 2 percentage points higher than in the baseline., while grace and maturity periods are the same as in the baseline.

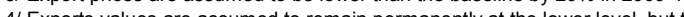

current account as a share of GDP is assumed to return to its baseline level after the shock $5 /$ includes officil and private transfers and FDl.

6/ Depreciation is defined as percentage decline in dollar/local currency rate, such that it never exceeds 100 percent

7/ Applies to all stress scenarios except for A2 (less favorable financing) in which the terms on all new financing are as specified in footnote 2 . 
Figure 1. Papua New Guinea: Indicators of Public and Publicly Guaranteed External Debt under Standard Alternatives Scenarios, 2008-28 1/
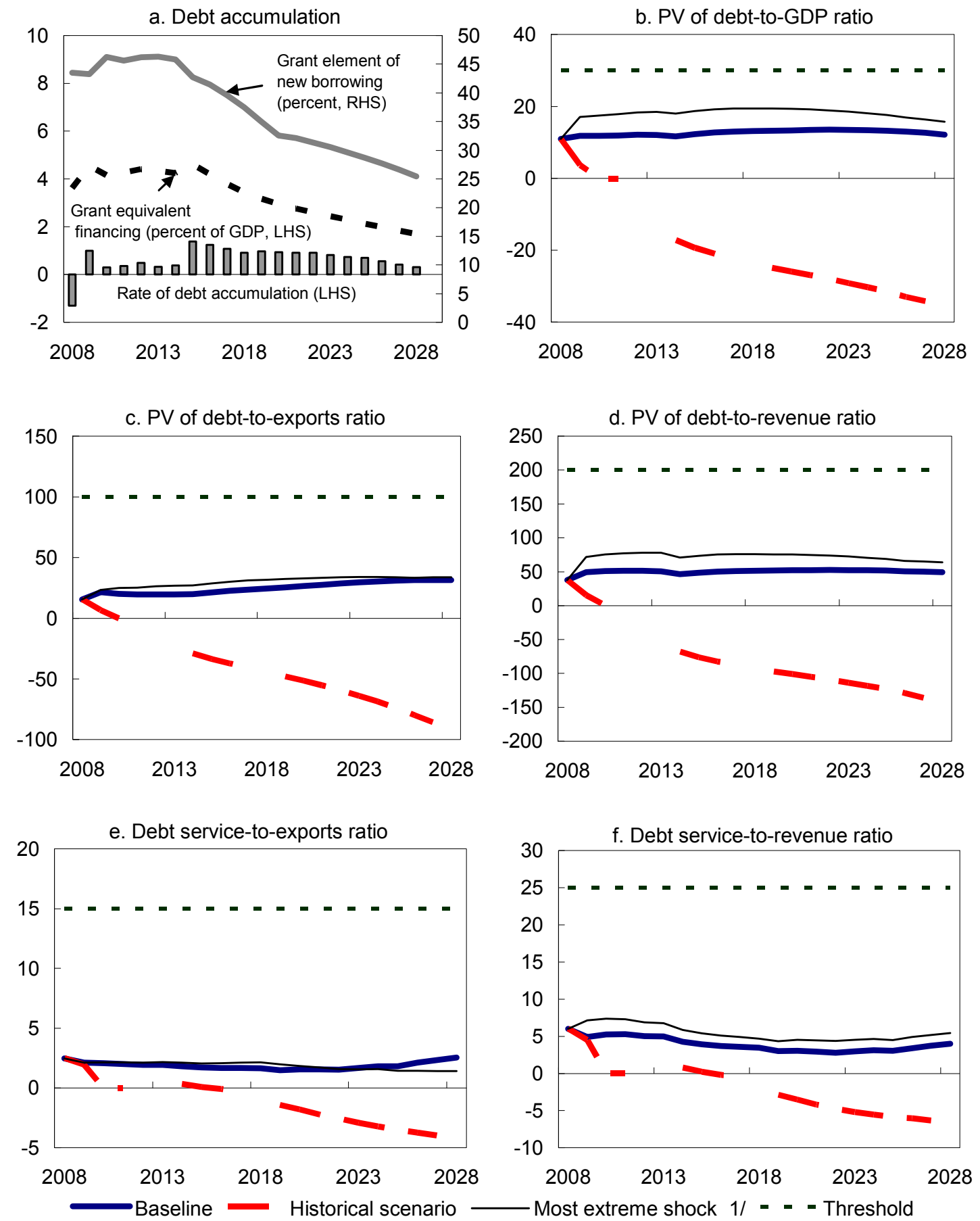

Source: Staff projections and simulations.

1/ The most extreme stress test is the test that yields the highest ratio in 2018. 
Figure 2. Papua New Guinea: Indicators of Public Debt Under Standard Alternative Scenarios, 2008-28 1/
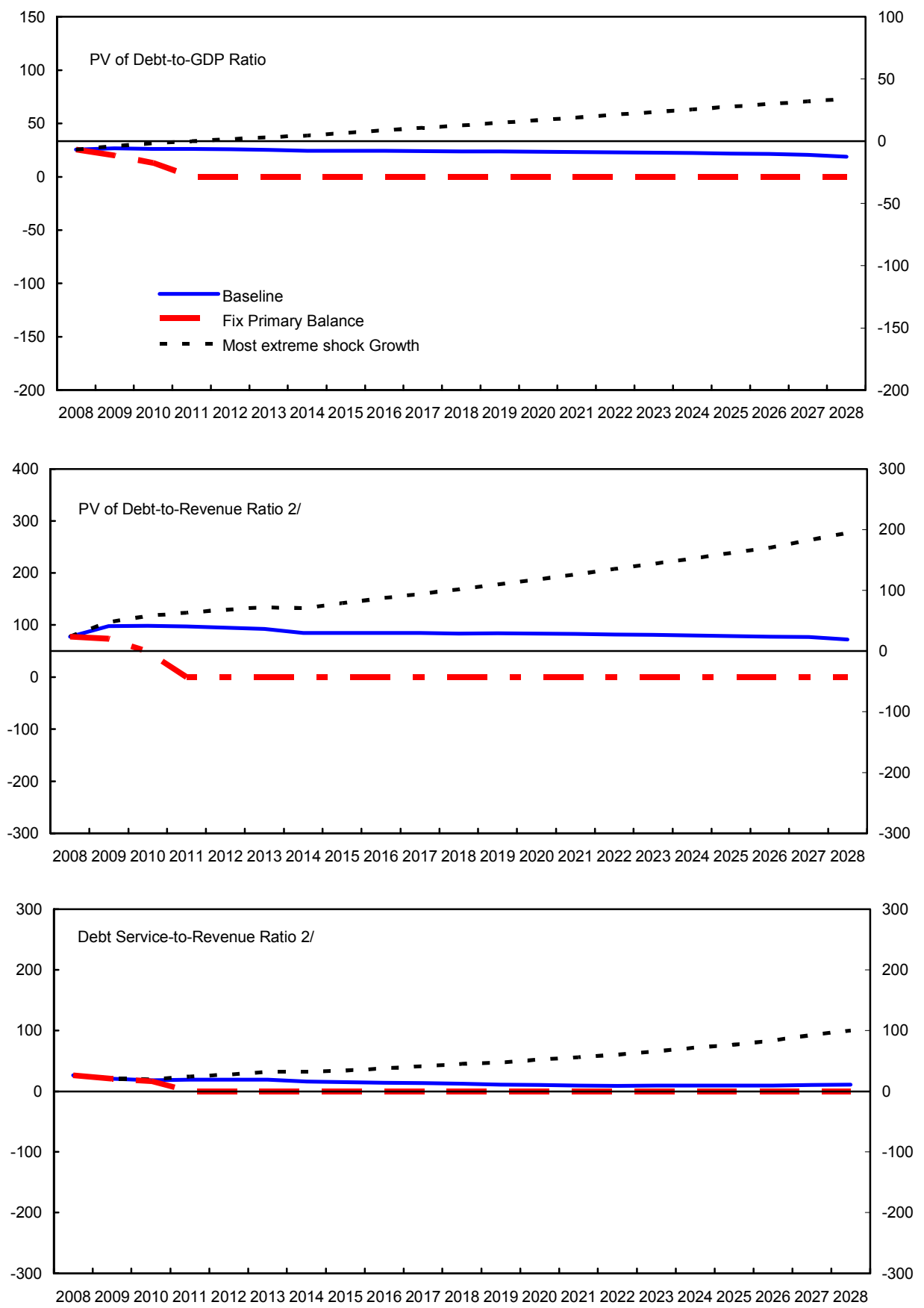

Sources: Country authorities; and Fund staff estimates and projections.

$1 /$ The most extreme stress test is the test that yields the highest ratio in 2018.

2/ Revenues are defined inclusive of grants.

\section{CInternational Monetary Fund. Not for Redistribution}




\section{INTERNATIONAL MONETARY FUND}

\section{PAPUA NEW GuINEA}

\section{Staff Report for the 2008 Article IV Consultation-Informational Annex}

Prepared by the Asia and Pacific Department

February 27, 2009

Contents Page

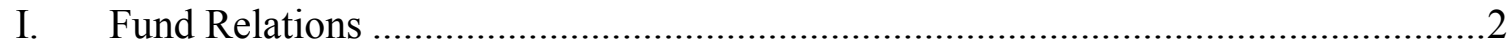

II. Relations with the Pacific Financial Technical Assistance Centre ...........................4

III. Relations with the World Bank Group.................................................................6

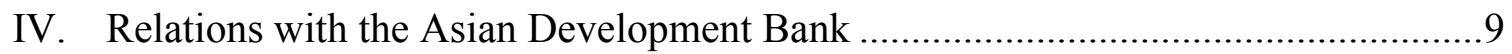

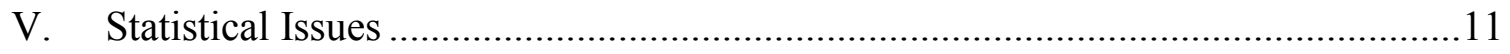


Annex I: Papua New Guinea-Fund Relations

(As of January 31, 2009)

I. Membership Status: Joined October 9, 1975; Article VIII

II. General Resources Account:

Quota

Fund holdings of currency

Reserve position in Fund

III. SDR Department:

Net cumulative allocation

Holdings
SDR Million

131.60

131.16

0.44

SDR Million

9.30

0.07
Percent Quota

100.00

99.67

0.33

Percent Allocation

100.00

0.77

IV. Outstanding Purchases and Loans: None

V. Financial Arrangements:

$\begin{array}{lcccc}\text { Type } & \begin{array}{c}\text { Approval } \\ \text { Date }\end{array} & \begin{array}{c}\text { Expiration } \\ \text { Date }\end{array} & \begin{array}{c}\text { Amount Approved } \\ \text { (SDR Million) }\end{array} & \begin{array}{c}\text { Amount Drawn } \\ \text { (SDR Million) }\end{array} \\ \text { Stand-by } & 7 / 31 / 91 & 9 / 30 / 92 & 26.36 & 0.00 \\ \text { Stand-by } & 7 / 14 / 95 & 12 / 15 / 97 & 71.48 & 35.34 \\ \text { Stand-by } & 3 / 29 / 00 & 9 / 28 / 01 & 85.54 & 85.54\end{array}$

VI. Projected Obligations to Fund ${ }^{1}$ (SDR million; based on existing use of resources and present holdings of SDRs):

\begin{tabular}{lrrrrr} 
& \multicolumn{5}{c}{ Forthcoming } \\
& $\mathbf{2 0 0 9}$ & $\mathbf{2 0 1 0}$ & $\mathbf{2 0 1 1}$ & $\mathbf{2 0 1 2}$ & $\mathbf{2 0 1 3}$ \\
Principal & 0.00 & 0.00 & 0.00 & 0.00 & 0.00 \\
Charges/interest & $\underline{0.06}$ & $\underline{0.05}$ & $\underline{0.05}$ & $\underline{0.05}$ & $\underline{0.05}$ \\
Total & $\underline{0.06}$ & $\underline{0.05}$ & $\underline{0.05}$ & $\underline{0.05}$ & $\underline{0.05}$
\end{tabular}

${ }^{1 /}$ When a member has overdue financial obligations outstanding for more than three months, the amount of such arrears will be shown in this section.

\section{Safeguards Assessments:}

Under the Fund's safeguards assessment policy, the Bank of Papua New Guinea (BPNG) was subject to a transitional assessment based on its Stand By Arrangement (SBY) with the Fund, which was approved in March 2000 and expired in September 2001. The transitional assessment was completed on May 4, 2001 and made recommendations to alleviate identified weaknesses. Currently, the BPNG is not subject to the safeguards policy.

\section{Exchange Rate Arrangement:}

Papua New Guinea has a floating exchange rate arrangement; the exchange rate of the kina is determined in the interbank market in which authorized banks participate. Papua New Guinea has accepted the obligations of Article VIII, Sections 2, 3, and 4, and maintains an exchange system free of restrictions on payments and transfers for current international transactions. 


\section{Article IV Consultation:}

The 2007 Article IV consultation discussions were held during November 1-14, 2007. It was concluded by the Executive Board on February 15, 2008 (IMF Country Report No. 08/98). Papua New Guinea is on the 12-month cycle.

\section{Technical Assistance from Headquarters:}

FAD: A joint FAD/PFTAC mission in March 2000 assisted the authorities in preparing a Report on the Observance of Standards and Codes Fiscal Transparency Module, published in October 2000. A mission in December 2000 provided advice on the reconciliation of large and volatile differences in fiscal reporting based on information provided by the Treasury Department and information reported by the Bank of Papua New Guinea. A mission in February 2002 assessed progress in improving fiscal transparency.

LEG: A mission in November 1996 provided advice on the legal framework for the National Value-Added Tax. A mission in November 2005 provided advice on the drafting of a tax administration law. A mission in July 2006 provided a comprehensive program of assistance in the development of the AML/CFT regime, including legislative drafting and capacity building. A mission in August/September 2007 assisted the authorities in finalizing the terms of the Revenue Administration Bill.

MFD/MCM: A mission in November 2001 reviewed foreign exchange management. A mission in June 2001 assessed the monetary policy implementation framework. During 2001-03 assistance was provided through missions in bank supervision, financial sector restructuring and improving the accounting framework and monetary operations of the central bank. A resident advisor was assigned to the BPNG research department for 15 months through August 2003. Technical assistance through peripatetic visits was delivered on bank regulation and supervision (2001-February/March 2007), medium-term monetary policy formulation (October 2004 and September 2005), reserve management (June 2006-September 2007), internal audits (2004August 2007), accounting (September/October 2006-February 2007), and liquidity management (January 2009).

STA: Four missions in 1995-96 provided advice on the compilation of national accounts. A mission reviewed monetary and financial statistics in April 2005 and to follow-up missions took place in May 2006, and in April 2008. Subsequently, a multisector mission visited in September 2006 followed by a high level STA mission in December 2007.

\section{Resident Representative: None}




\section{ANNEX II: Papua New Guinea-Relations With the Pacific Financial TeChNiCAl ASSistance Centre ${ }^{1}$ \\ (As of October 27, 2008)}

Until the Resident Representative position was closed in May 2008, the resident representative helped coordinating TA assistance to Papua New Guinea (PNG), with the extensive assistance provided by the Australian Enhanced Cooperation Program (ECP). Since 2000, PFTAC has provided more than 24 missions to PNG, and the Government has sent over 50 officials to the Centre's regional seminars, workshops, and training courses in this period.

\section{Public Financial Management}

PFTAC assisted in the preparation of a ROSC, which was published in October 2000. The PFTAC PFM Advisor has participated in occasional FAD technical assistance missions, and an attachment of one PNG official to PFTAC was completed in April 2007. PNG participated, with four officials, in the US Treasury study visit in September 2008.

\section{Tax Administration and Policy}

The IMF Legal Department drafted a Tax Administration Act in 2005, adopted by the Government in 2006, that: (i) the re-established the Internal Revenue Commission as an independent tax authority; and (ii) included customs administrative provisions. An IMF Legal Department mission in September 2007 prepared the Internal Revenue Commission Administration Bill 2007 to strengthen and consolidate all revenue administrative provisions into one statute. It is expected that the new law will shortly be passed by the Parliament.

PFTAC has delivered a project to: objectively assess the existing IT system of the Internal Revenue Commission and; develop and draft an information technology strategic plan (ITSP) and: based on the ITSP, draft a business plan for the redevelopment of the IT system. The project comprised of six missions over the period June 2006 to May 2008 and delivered the following:

- An assessment of the current and future business drivers.

- Development of the business system architecture for the ITSP.

- Completion of the applications, information and IT technical architecture phases of the ITSP project.

\footnotetext{
${ }^{1}$ The Pacific Financial Technical Assistance Centre (PFTAC) in Suva, Fiji is a regional technical assistance institution operated by the IMF with financial support of the Asian Development Bank, Australia, Korea, Japan and New Zealand. The Center's aim is to build skills and institutional capacity for effective economic and financial management that can be sustained at the national level. Member countries are: Cook Islands, Federated States of Micronesia, Fiji, Kiribati, Marshall Islands, Nauru, Niue, Palau, Papua New Guinea, Samoa, Solomon Islands, Tokelau, Tonga, Tuvalu, and Vanuatu.
} 
- Recommendations for the management and delivery of IT services within the IRC.

- Completion and approval of the ITSP Transition Plan.

- Drafting of the request for information (RFI) to test the market availability of suitable tax administration packaged software.

- Development of a business case to fund redevelopment of the Internal Revenue Commission (IRC) technology system, that is suitable for presentation and decision making by the Government of PNG and other potential donor organisations.

\section{Financial Sector Regulation and Supervision}

There is no current PFTAC involvement in this area, as technical assistance is provided by MCM, but the Advisor visited BPNG in September 2004 and July 2005 to identify areas where technical assistance could be provided. In October 2005, the BPNG hosted the annual meeting of the Association of Financial Supervisors of Pacific Countries, for which PFTAC is the secretariat. In March 2007, PFTAC funded an attachment for two supervisors from BPNG to assist the Cook Islands' supervisory authority to undertake an on-site examination of a domestic bank. In 2008, PFTAC funded an attachment of one supervisor to assist the Reserve Bank of Fiji under an on-site examination of a local branch of a PNG-based bank.

\section{Economic and Financial Statistics}

In February 2006, the Advisor briefly assessed the BOP compilation with a view to improve its quality, and to assess progress against recommendations made by previous missions. A multi-sector statistics mission in September 2006 assessed the statistical systems (BOP, national accounts, prices statistics, government finance statistics and monetary statistics), with the PFTAC Advisor assessing the national accounts and providing overall coordination. The BOP expert provided some TA to progress improvements to the methodology and source data. In June 2008 the Advisor undertook a balance of payment (BOP) statistics mission to Papua New Guinea (PNG) to review statistics prerequisites, progress in improving compilation methods and source data, as well as to assist Bank of PNG statistics staff in assessing the feasibility of electronic data collection. 


\section{Annex III: Papua New Guinea-Relations With The World Bank Group}

(As of February 5, 2009)

The World Bank Group has a long history of engagement in Papua New Guinea (PNG). PNG formally became a member of the World Bank upon gaining independence in 1975 but had been a recipient of loans from the World Bank since 1968. To date, the World Bank has provided PNG with 36 IBRD loans totaling US\$786.6 million and 16 IDA credits totaling US\$195.0 million in commitments.

The Bank's relationship with the Government of PNG in 2003-06 was uneven as a result of a suspension and later cancellation of the Forestry Conservation Project. Between 2003 and 2006 the World Bank did not approve any loans or credits for PNG and focused instead on analytical and outreach activities.

Following a significant improvement in political stability, macroeconomic performance and general relationship with the Government, the Bank, in close consultation with the Government, prepared in 2007 a full four-year CAS, which was approved by the Bank's Board of Directors on December 18, 2007. The FY08-11 CAS is designed to launch a long-term partnership between the Bank and PNG aimed at supporting sound management of economy and natural resources, and addressing immediate livelihood and service delivery needs of the poor people, while also building a foundation for tackling longer-term institutional and accountability challenges. Empowering women and youth and strengthening governance have been prioritized as crosscutting themes.

Under the FY08-11 CAS, the World Bank provides PNG with concessional financial resources on the order of US $\$ 40$ million per year ${ }^{2}$ and assists the country in accessing global and regional grant funds such as Global Environmental Facility. In accordance with the Strategy, the Bank has already approved a Smallholder Agriculture Development Project (US\$27.5 million; approved by the Board in December 2007) and Second Mining Sector Institutional Strengthening Project (US\$17.0 million; approved in June 2008). Together with the Road Maintenance and Rehabilitation Project totaling US\$40.0 million in IBRD and US\$37.3 million in IDA commitments, these projects represent the World Bank's current credit portfolio in PNG. In addition to the loan and credits, the Bank is also currently implementing a Global Environment Facility-supported Teachers' Solar Lighting Project (US\$0.99 million) and the regional Sustainable Energy Financing Project, which covers also PNG.

In line with PNG's medium-term debt strategy which envisions limiting external public borrowing primarily to concessional terms and using mineral windfall revenue for early repayment of more expensive debt, in late 2007 the Government pre-paid seven IBRD loans totaling US\$56 million. As a result, PNG's debt outstanding to the World Bank as end-

\footnotetext{
${ }^{2}$ PNG is formally a blend IBRD-IDA country. However, PNG's debt strategy does not provide for nonconcessional borrowing and no immediate IBRD lending to PNG is therefore envisioned.
} 
December, 2009 stood at US\$229.6 million compared to over US\$321.5 million at the end of 2006. In December 2008, the Government made an additional prepayment of four more IBRD loans totaling about US\$15 million.

The pipeline of the World Bank projects under preparation is rapidly expanding under the FY0811 CAS. Currently four projects are being prepared: Productive Partnership in Agriculture (focusing on coffee and cocoa sub-sectors), Rural Service Delivery and Local Governance (focusing on small community-level development projects), Urban Youth Empowerment (aiming at expanding opportunities for urban youth) and Rural Telecommunications (which will create a fund to roll out telecommunications services to uneconomic areas). The Bank is also moving forward with mobilizing global grant resources for PNG, in particular through the Fast Track Initiative for Education. Two more projects - Rural Electrification and Health - are at the concept stage.

The Bank's analytical work and technical assistance include economic monitoring and reporting, dialogue with the Government as part of the programmatic Public Expenditure Review and Rationalization process, and support to the nationally representative Household Income and Expenditure Survey (jointly with AusAID). The Bank is also assisting the Government in preparing a Climate Change Strategy. The Bank's support to civil society has consisted of two rounds of the Development Marketplace-type Youth Competition (in 2006 and 2008) which provided small grants to promising grassroots development project. The Bank has also been involved in a number of community outreach activities through its Global Development Learning Network and Public Information Center. As part of its strengthening commitment to PNG, the Bank has also expanded the staff of its Port Moresby office.

The Bank's private sector arm, International Financial Corporation, has also strengthened the level of its engagement in PNG over the past few years. IFC's Advisory Services-Pacific (IFC AS Pacific) established a full-time presence in PNG in early 2006, co-located with the World Bank. Since then IFC advisory service activity in PNG has increased considerably, with a focus on access to finance, tourism, the business environment, and infrastructure.

Within these programs IFC AS Pacific is working to: improve the capacity of commercial banks to provide credit; increase the availability of finance and financial services for the poor, including investment in PNG Microfinance; assist in building financial infrastructure, including establishment of a credit referral bureau; improve the business environment by working on a subset of the Doing Business indicators, in collaboration with the Foreign Investment Advisory Service; strengthen the tourism sector; improve agribusiness production, quality, supply chains and marketing; and explore - jointly with the Bank - opportunities to support growth in the commercial fisheries sector, including enabling work on a special economic zone to host regional tuna processing.

The IFC's current investment portfolio in PNG consists of a US\$1.2 million equity commitment to PNG Microfinance Limited, of which US\$756 thousand has already been disbursed, giving the IFC a 19 percent shareholding in the bank. The equity investment is supported by a US\$2 million institutional capacity building program presently under implementation. The IFC has also 
provided Digicel PNG Ltd with a US\$40 million line of credit to support the roll-out of its national mobile telephony network, and a US\$44 million line of credit to global agribusiness company ECOM Ltd. for coffee supply chain improvement across 6 countries, including PNG. In addition, the IFC is tracking investment opportunities in agribusiness, gas and mining, infrastructure, and forestry.

The Multilateral Investment Guarantee Agency (MIGA) has provided one guarantee in PNG. The guarantee worth US\$76.6 million in gross exposure covers a portion of equity investment and a loan by a syndicate of commercial lending institutions for the Lihir open-pit gold mine. The guarantee facilitated several hundred million US\$ in foreign investment in PNG.

\section{Papua New Guinea: IBRD/IDA Lending Operations (In millions of U.S. dollars)}

\begin{tabular}{|c|c|c|c|c|c|c|c|c|c|c|}
\hline Fiscal Year & 2000 & 2001 & 2002 & 2003 & 2004 & 2005 & 2006 & 2007 & 2008 & $2009^{*}$ \\
\hline Commitments & 132.3 & 0 & 57.3 & 0 & 0 & 0 & 0 & 37.3 & 44.5 & 0 \\
\hline Disbursements & 39.8 & 11.3 & 65.1 & 7.3 & 7.8 & 10.9 & 22.4 & 20.7 & 1.4 & 5.9 \\
\hline Undisbursed balance & 134.5 & 114.1 & 106.4 & 85.8 & 77.1 & 51.1 & 28.3 & 45.4 & 92.4 & 82.9 \\
\hline Debt service ${ }^{\star *}$ & 49.9 & 43.8 & 39.3 & 37.7 & 36.0 & 32.8 & 39.8 & 40.3 & 92.0 & 28.5 \\
\hline
\end{tabular}

Note: Fiscal year is July-June.

* As of December 31, 2008.

** Including debt prepayment of around US\$56 million in December 2007 and around US\$15 million in December 2008. 


\section{Annex IV: Papua New Guinea-Relations With the Asian DeVelopment BanK ${ }^{3}$}

(As of February 4, 2009)

The Asian Development Bank (AsDB) has approved 63 loans to Papua New Guinea (PNG) totaling \$1,127 million for 48 projects, of which 26 loans (\$558 million) have been extended from ordinary capital resources (OCR) while 37 loans (\$569 million) from the Asian Development Fund (ADF). AsDB also provided one ADF grant amounting $\$ 15$ million. In addition, technical assistance (TA) grants ( $\$ 54.4$ million) have been provided for $137 \mathrm{TA}$ projects. There are currently 9 active loans and grant involving 6 projects and one ADF grantfinanced project.

In 2008, the AsDB approved a Highlands Region Road Improvement Investment Program of $\$ 100$ million loan from ADF resources. Four TA projects totaling \$3.0 million were approved for the Power Sector Development project, the Pilot Border Trade and Investment Development project, National Transport Development Plan (2011-2020), and support for development planning.

A Country Program Strategy Mid-Term Review in December 2008 confirmed the rationale and validity of the Country Strategy and Program for 2006-2010, which focuses on four key strategic areas including (i) public financial management, (ii) private sector development, (iii) the transport sector, and (iv) health and HIV/AIDS. Furthermore, the AsDB also sees the potential to broaden its infrastructure support in general, and is prepared to support the development of power sector and civil aviation in PNG. The AsDB is of the view that increased development investment is essential to reduce poverty in PNG, where infrastructure investment is much needed and many people lack access to basic services. The AsDB stands ready to expand its current lending program in line with the Government's Medium Term Development Strategy.

As a key feature of the AsDB's work in PNG, the AsDB continued close cooperation with development partners through Government-led processes to increase aid effectiveness. Furthermore, consistent with the AsDB's managing for development results action plan to improve its effectiveness in reducing poverty and promoting development in the Asia and Pacific region, the AsDB supports the government's work to develop its own results-management framework and adopts the government's performance targets and indicators in the preparation of the country operations and business plan for PNG.

Through its private sector operations, the AsDB has made investments in two private equity funds - Kula Fund I and Kula Fund II Limited - aggregating to \$8 million, that provided assistance to enterprises in the AsDB's Pacific developing member countries, including PNG. In addition, the AsDB assisted the Government to prepare its Public Private Partnership (PPP) policy, which was approved by the National Executive Council (NEC) in late 2008. The AsDB will provide further support in the next phase of PPP policy implementation, for: (i) legislation and regulations; (ii) establishing a PPP Center; and (iii) consolidating a national infrastructure list

\footnotetext{
${ }^{3}$ Prepared by AsDB staff.
} 
for possible PPP application. The AsDB also funded an assessment of the current market, technology and regulatory environment for mobile banking in PNG.

Papua New Guinea: Loan Approvals and Disbursements, 2002-08

(In millions of U.S. dollars)

\begin{tabular}{lccccccc}
\hline & 2002 & 2003 & 2004 & 2005 & 2006 & 2007 & 2008 \\
\hline Loan approvals & 5.7 & 0.0 & 19.0 & 0.0 & 53.0 & 100.0 & 100.0 \\
Loan disbursements & 14.0 & 13.8 & 19.2 & 21.5 & 29.3 & 27.4 & 11.4 \\
\hline
\end{tabular}




\section{AnNex V: Papua New Guinea-STatistical Issues \\ As of February 18, 2009}

\section{Assessment of Data Adequacy for Surveillance}

General: Data provision has some shortcomings, but is broadly adequate for surveillance. Most affected areas are: national accounts, fiscal accounts, and balance of payments.

National Accounts: The National Statistical Office (NSO) lacks sufficient staff with computer training. The accuracy and reliability of the data are affected by inadequate source data. The Bank of Papua New Guinea (BPNG) and the Department of Treasury produce the most current data. In mid-2000, the NSO released a set of national accounts estimates: National Income, Expenditure and Product, 1993-98. These estimates were compiled using the 1968 System of National Accounts. However, the NSO has been working to implement the 1993 SNA. In March 2004, the NSO released a preliminary set of national income, expenditure, and production accounts estimates for 1994-2002, rebased to 1998 prices. As these figures are still in need of substantial improvements, the 2006 STA multisector mission recommended against publication of the new GDP data until the needed revisions are made. In an attempt to fill the vacuum, the Treasury-responsible for Government finance statistics (GFS) - has actually assumed the role of estimating the NA for 2002 to the present.

Price statistics: The NSO currently compiles a new quarterly wholesale price index (which it does not publish) and a quarterly consumer price index that is based on weights that are thirty fine years old. The NSO intends to use the results of the planned Household Income Expenditure Survey (HIES) to rebase the CPI; however, this has been delayed for a long time.

Government finance statistics: Annual GFS reported to STA suffer from insufficient coverage. While central government tax revenue statistics are generally accurate and timely, nontax revenue and public expenditure data are deficient. In particular, development budget expenditures and the utilization of grants and project loans are recorded with long lags, and few records on the use of accrual trust accounts are available. While interest payment records are accurate, there are timing issues regarding the recording of interest on discount securities. These weaknesses contribute to discrepancies in domestic financing between estimates from monetary and debt data and those derived from fiscal records. The 2006 STA multisector mission encouraged the authorities to prepare a list of public sector units to permit a comprehensive delineation of the levels of government, which should help reconcile the GFS with other datasets.

Monetary statistics: Monetary data are now being produced on a regular basis and reporting to STA has improved. Three monetary and financial statistics missions (April 2005, May 2006, and April 2008) visited Papua New Guinea which helped to (i) finalize the review of the collection, compilation, and dissemination procedures of monetary statistics by the BPNG; (ii) develop a work program to facilitate the full implementation of the methodology recommended in the Monetary and Financial Statistics Manual (MFSM); (iii) prepare the standardized report forms (SRFs) for reporting monetary data of the central bank, other depository corporations, and monetary aggregates; and (iv) finalize the integrated monetary database that meets the data needs of the BPNG, STA, and APD. Due to the importance of the other financial corporations (OFCs), a follow-up mission is scheduled for early 2009 to introduce the SRF for the OFCs based on the newly introduced call report forms to obtain balance-sheet data and compile a financial corporations survey.

Balance of payments: Annual balance of payments data are derived from the International Transactions Reporting System (ITRS), which is not tightly monitored despite the BPNG reporting requirements. There are marked differences between the official data on exports and imports of goods and those reported by trading partners. The financial accounts data are of poor quality because of major deficiencies in data collection, especially in the areas of private external debt. Quarterly data are also published by the BPNG. The 2006 STA multisector mission identified as a priority to strengthen current account estimates, including through improved classification of investment earnings, trade credits, and grant receipts as well as enhancing source data for imports and exports. Progress is being made to implement the recommendations from the PFTAC's BOP mission in June 2008. Detailed BOP statistics are under review to be released in the near future. 


\section{Data Standards and Quality}

Does not participate in the General Dat No data ROSC is available.

Dissemination System.

III. Reporting to STA

Papua New Guinea last reported government finance statistics for publication in the Government Finance Statistics Yearbook and in International Financial Statistics for 1999-2002 and cover only budgetary central government.

Monetary data are reported to STA for publication in the IFS and IFS Supplement on Monetary and Financial Statistics on a regular monthly basis.

Balance of payments data for 2005 were reported to STA for publication in the IFS and in BOPSY

National accounts data for 2004 were reported to STA for publication in the IFS

\section{PaPUa NeW GuINeA: TABLE OF COMMON INDICATORS REQUIRED FOR SURVEILLANCE}

(As of February 18, 2009)

\begin{tabular}{|c|c|c|c|c|c|}
\hline & $\begin{array}{c}\text { Date of Latest } \\
\text { Observation }\end{array}$ & $\begin{array}{c}\text { Date } \\
\text { Received }\end{array}$ & $\begin{array}{c}\text { Frequency } \\
\text { of Data }^{7}\end{array}$ & $\begin{array}{c}\text { Frequency of } \\
\text { Reporting }^{7}\end{array}$ & $\begin{array}{l}\text { Frequency of } \\
\text { Publication }^{7}\end{array}$ \\
\hline Exchange rates & $02 / 13 / 09$ & $02 / 17 / 09$ & $\mathrm{D}$ & $\mathrm{W}$ & W \\
\hline International reserve assets and reserve liabilities of the monetary authorities ${ }^{1}$ & $02 / 13 / 09$ & $02 / 17 / 09$ & W & $\mathrm{W}$ & Q \\
\hline Reserve/base money & $12 / 08$ & $02 / 09 / 09$ & M & M & Q \\
\hline Broad money & $12 / 08$ & 02/09/09 & M & M & Q \\
\hline Central bank balance sheet & $12 / 08$ & 02/09/09 & M & M & Q \\
\hline Consolidated balance sheet of the banking system & $12 / 08$ & 02/09/09 & M & M & Q \\
\hline Interest rates $^{2}$ & $12 / 31 / 08$ & 02/06/09 & $\mathrm{W}$ & $\mathrm{W}$ & Q \\
\hline Consumer price index & $09 / 08$ & $11 / 08$ & Q & Q & Q \\
\hline Revenue, expenditure, balance and composition of financing ${ }^{3}$ - general government ${ }^{4}$ & $\mathrm{~N} / \mathrm{A}$ & N/A & N/A & N/A & $\mathrm{N} / \mathrm{A}$ \\
\hline Revenue, expenditure, balance and composition of financing ${ }^{3}$-central government & 07/08 & $09 / 08$ & M & Q & Q \\
\hline Stocks of central government and central government-guaranteed debt ${ }^{5}$ & $09 / 07$ & $11 / 07$ & Q & Q & Q \\
\hline External current account balance & $09 / 08$ & $12 / 08$ & Q & Q & Q \\
\hline Exports and imports of goods and services & 09/08 & $12 / 08$ & Q & Q & Q \\
\hline GDP/GNI & 2007 & $11 / 08$ & A & A & A \\
\hline Gross external debt & 2007 & $11 / 08$ & Q & A & A \\
\hline International Investment Position ${ }^{6}$ & & & & & \\
\hline
\end{tabular}

${ }^{1}$ Includes reserve assets pledged or otherwise encumbered as well as net derivative positions.

${ }^{2}$ Both market-based and officially determined, including discount rates, money market rates, rates on treasury bills, notes, and bonds.

${ }^{3}$ Foreign, domestic bank, and domestic nonbank financing.

${ }^{4}$ The general government consists of the central government (budgetary funds, extra budgetary funds, and social security funds) and state and local governments.

${ }^{5}$ Including currency and maturity composition.

${ }^{6}$ Includes external gross financial asset and liability positions vis-à-vis nonresidents.

${ }^{7}$ Daily (D), Weekly (W), Monthly (M), Quarterly (Q), Annually (A); Irregular (I); and Not Available (NA). 


\section{INTERNATIONAL MONETARY FUND}

EXTERNAL

RELATIONS

Public Information Notice

DEPARTMENT

Public Information Notice (PIN) No. 09/44

FOR IMMEDIATE RELEASE

April 3, 2009

International Monetary Fund

$70019^{\text {th }}$ Street, NW

Washington, D. C. 20431 USA

\section{IMF Executive Board Concludes 2008 Article IV Consultation with Papua New Guinea}

On March 16, 2009, the Executive Board of the International Monetary Fund (IMF) concluded the Article IV consultation with Papua New Guinea. ${ }^{1}$

\section{Background}

Macroeconomic performance has improved, but Papua New Guinea remains a poor country highly exposed to commodity price fluctuations. GDP per capita remains low and improvement has lagged other low-income countries in the region. An unattractive investment environment, due primarily to weak infrastructure, problems with and governance, and high crime curtails development.

Real GDP grew by 6.5 percent in 2007 , on the back of strong growth in the nonmineral sector. Leading indicators suggest that activity continued to expand rapidly in 2008 . After remaining in the low single digits during 2004-07, CPI inflation accelerated in late-2007, reaching nearly 13.5 percent (year-on-year) in September 2008.

In response to rising inflation the Bank of Papua New Guinea (BPNG) has increased the policy interest rate during the second half of 2008. However, monetary conditions remain accommodative as rising inflation has reduced real lending rates. In the last few years, the fiscal balance has been in surplus, with the mineral windfall largely saved and public debt reduced. For 2008, the estimated fiscal surplus is 41/2 percent of GDP, down from 8 percent in 2007.

\footnotetext{
${ }^{1}$ Under Article IV of the IMF's Articles of Agreement, the IMF holds bilateral discussions with members, usually every year. A staff team visits the country, collects economic and financial information, and discusses with officials the country's economic developments and policies. On return to headquarters, the staff prepares a report, which forms the basis for discussion by the Executive Board. At the conclusion of the discussion, the Managing Director, as Chairman of the Board, summarizes the views of Executive Directors, and this summary is transmitted to the country's authorities.
} 
To date, spillovers from the global financial market turmoil have been limited. Banks are very liquid and largely isolated from international capital markets. However, the stock market has weakened since its peak in June, in line with other stock markets in the region.

Both the real and nominal effective exchange rates were stable between 2003 and mid-August 2008, but have appreciated since then. Improved terms-of-trade delivered a sequence of current account surpluses that reduced external debt to about 27 percent of GDP at end-2008.

\section{Executive Board Assessment}

Executive Directors noted that Papua New Guinea was in a relatively favorable position at the onset of the global financial crisis. In particular, they commended the authorities for saving the bulk of recent windfall mineral revenues and repaying public debt to improve the external debt position. Directors noted that, while the banking system has only limited exposure to global financial markets, the deterioration in international economic conditions is having an impact. Owing to the collapse in commodity prices, lower export revenues are worsening both domestic and external balances.

Directors agreed that the current prudent monetary stance is appropriate. Despite the decline in food and energy prices, the authorities are paying due regard to risks that domestic price pressures could prevent a rapid decline in inflation. Given the downside risks to inflation associated with the deteriorating external environment, Directors considered it important to monitor developments closely and to be prepared to ease monetary policy if the domestic impact turns out more negative than expected.

Directors acknowledged the authorities' policy of slowing exchange rate depreciation to moderate inflationary pressures. Nevertheless, and noting the staff's assessment that the kina is mildly overvalued, they were generally of the view that the currency should be allowed to adjust to the sharp decline in commodity prices. This would help offset the impact on export incomes, safeguard foreign currency reserves, and help preserve external stability.

Directors welcomed the new Medium-Term Fiscal Strategy, observing that its full implementation will help maintain macroeconomic stability by reducing the risks associated with volatile mineral revenue. To enhance macroeconomic stability further, Directors encouraged the monetary and fiscal authorities to cooperate so as to ensure that the cyclical position of the economy determines the amount of spending from accumulated windfall revenues. Directors stressed that windfall revenues should be directed toward achieving the Medium-Term Development Strategy objectives and to support growth should the impact of the global slowdown be larger than expected.

Directors agreed that some easing in fiscal policy is warranted in 2009. Given domestic capacity constraints, in particular at the district level where a substantial increase in spending is planned, they nevertheless encouraged the authorities to adopt a less expansionary policy stance than envisaged and to protect the quality of public spending through careful prioritization. This would ensure that public demand does not stimulate inflation, and help maintain the level of public spending at a level consistent with medium-term fiscal sustainability. 
Directors noted that the financial sector has been relatively immune to the global financial crisis. The strains in international capital markets are not affecting liquidity because banks are funded primarily via domestic deposits. Given the impact of declining commodity prices on incomes, Directors encouraged the authorities to ensure that banks maintain strict lending standards and carefully monitor debt-servicing abilities and non-performing loans. They supported the authorities' request for an Financial Sector Assessment Program (FSAP).

Directors encouraged the authorities to expedite the pace of structural reform. To make progress on development objectives, they pointed to the need to reinvigorate public-sector reform programs in health, education, and law enforcement. Directors stressed that greater transparency of the financial conditions of state-owned enterprises and full transfer of their returns to general government revenue are desirable to ensure that the government has adequate resources to implement the reform agenda.

Given the importance of high quality and timely data for policy making, Directors stressed the need to press ahead with the improvement of economic statistics.

Public Information Notices (PINs) form part of the IMF's efforts to promote transparency of the IMF's views and analysis of economic developments and policies. With the consent of the country (or countries) concerned, PINs are issued after Executive Board discussions of Article IV consultations with member countries, of its surveillance of developments at the regional level, of post-program monitoring, and of ex post assessments of member countries with longer-term program engagements. PINs are also issued after Executive Board discussions of general policy matters, unless otherwise decided by the Executive Board in a particular case. 
Papua New Guinea: Selected Economic Indicators, 2005-09

\begin{tabular}{|c|c|c|c|c|c|}
\hline $\begin{array}{ll}\text { Nominal GDP (2007): } & \text { US } \$ 6.39 \text { billion } \\
\text { Population (2007): } & 6.3 \text { million } \\
\text { GDP per capita (2007): } & \text { US } \$ 1,012 \\
\text { Quota: } & \text { SDR } 131.6 \text { million }\end{array}$ & & & & & \\
\hline & 2005 & 2006 & 2007 & $\begin{array}{r}2008 \\
\text { Est. }\end{array}$ & $\begin{array}{l}2009 \\
\text { Proj. }\end{array}$ \\
\hline \multicolumn{6}{|l|}{ Real sector (percent change) } \\
\hline Real GDP growth & 3.6 & 2.6 & 6.5 & 7.0 & 3.9 \\
\hline Mineral & 5.0 & -5.9 & 0.2 & 4.8 & 2.6 \\
\hline Nonmineral & 3.4 & 3.8 & 7.3 & 7.2 & 4.1 \\
\hline CPI (annual average) & 1.8 & 2.4 & 0.9 & 10.7 & 8.2 \\
\hline CPI (end-period) & 4.7 & -0.9 & 3.2 & 11.2 & 5.3 \\
\hline \multicolumn{6}{|l|}{ Central government operations (percent of GDP) } \\
\hline Revenue and grants & 34.9 & 36.7 & 37.3 & 32.6 & 27.1 \\
\hline Expenditure and net lending & 31.2 & 30.0 & 29.2 & 28.1 & 29.1 \\
\hline Overall balance, cash basis (including grants) $1 /$ & 3.7 & 6.7 & 8.2 & 4.4 & -2.0 \\
\hline Overall balance, cash basis (including grants) 2/ & 3.8 & 5.6 & 7.2 & 4.4 & -2.0 \\
\hline Nonmineral balance 2/ & -4.7 & -7.6 & -6.8 & -6.8 & -7.2 \\
\hline \multicolumn{6}{|l|}{ Money and credit (end-period percentage change) } \\
\hline Domestic credit & 8.6 & 19.4 & 5.5 & -4.5 & 15.7 \\
\hline Credit to the private sector & 23.7 & 38.2 & 34.4 & 39.4 & 21.3 \\
\hline Broad money & 29.5 & 38.9 & 27.8 & 11.2 & 17.7 \\
\hline Interest rate (182-day T-bills; period average) & 3.8 & 3.7 & 4.4 & 6.0 & $\ldots$ \\
\hline \multicolumn{6}{|l|}{ Balance of payments (millions of U.S. dollars) } \\
\hline Exports, f.o.b. & 3,278 & 4,207 & 4,750 & 5,397 & 4,197 \\
\hline Of which: Mineral & 2,467 & 3,391 & 3,709 & 4,104 & 3,063 \\
\hline Imports, c.i.f. & $-2,462$ & $-2,805$ & $-3,331$ & $-3,794$ & $-3,521$ \\
\hline Current account (including grants) & 205 & 128 & 112 & 228 & -546 \\
\hline (In percent of GDP) & 4.1 & 2.3 & 1.8 & 2.8 & -6.7 \\
\hline Overall balance & 315 & 661 & 657 & 5 & 50 \\
\hline \multicolumn{6}{|l|}{ Reserves and external debt (end-period; millions of U.S. dollars) } \\
\hline Net international reserves & 765 & 1,425 & 2,083 & 2,090 & 2,140 \\
\hline (In months of goods and services imports) & 2.4 & 3.8 & 4.7 & 4.3 & 4.7 \\
\hline Public external debt-service-ratio (percent of exports) $3 /$ & 6.0 & 3.5 & 4.1 & 2.5 & 2.1 \\
\hline Public external debt-to-GDP ratio (in percent) $3 /$ & 25.4 & 21.1 & 16.7 & 12.2 & 14.7 \\
\hline \multicolumn{6}{|l|}{ Exchange rates } \\
\hline US\$/kina (period-average) & 0.3273 & 0.3288 & 0.3416 & 0.3731 & $\ldots$ \\
\hline US\$/kina (end-period) & 0.3230 & 0.3310 & 0.3618 & 0.3735 & $\ldots$ \\
\hline $\operatorname{NEER}(2000=100$, end-period $)$ & 80.7 & 78.0 & 77.7 & 95.0 & $\ldots$ \\
\hline $\operatorname{REER}(2000=100$, end-period $)$ & 104.2 & 98.0 & 98.7 & 135.2 & $\ldots$ \\
\hline Nominal GDP (millions of kina) & 15,195 & 17,132 & 18,716 & 22,246 & 22,362 \\
\hline
\end{tabular}




\section{Statement by Christopher Legg, Alternate Executive Director for Papua New Guinea March 16, 2009}

Papua New Guinea's recent economic history has been one of sustained growth and stability, underpinned by a favourable external environment - in particular, high prices for its commodity exports - sound domestic policy settings, and progress on important structural reforms. The global financial crisis, and the associated sharp downturn in global activity, clearly poses significant policy challenges for the authorities, while last year also saw a pickup in inflationary pressures associated with higher food and energy prices, demand pressures associated with a major resource development, and strong growth in bank liquidity, while monetary policy settings have been tightened in response. On the fiscal side, the authorities have chosen to use a portion of the earlier accumulated savings from the commodity price boom to buttress domestic demand and improve the provision of services and infrastructure essential to enhancing the productive capacity of the economy and addressing development needs.

GDP growth is expected to remain robust in 2009, if somewhat more subdued than the very strong performance of the last two years. The continued strength of activity in the mining and agricultural sectors is expected to offset declines in the petroleum sector, while structural reforms in telecommunications are expected to sustain growth in the non-mining sector, albeit below the unprecedented levels of recent years. The coming year should see a continuation of solid growth, albeit at a lower rate than the $7.2 \%$ achieved in 2008 . There is also some evidence of an easing in inflationary pressures, with measures of underlying trend inflation showing some moderation through the June and September 2008 quarters. While the external current account is expected to shift into deficit in 2009, holdings of international reserves are expected to remain high, at around five months import cover according to Fund estimates. Nevertheless, the authorities acknowledge the need for policy settings to remain responsive to the significant downside risks associated with the deteriorating global environment.

PNG continues to face daunting development challenges, compounded by the nation's impenetrable geography and ethnic and cultural diversity - with over 800 spoken languages, PNG is the most linguistically complex country in the world. This inevitably influences the political economy of reform. Indeed, the re-election of the Somare Government in 2007 for a second five-year term represents a period of political stability unprecedented in recent PNG history. In the area of economic policy, it has facilitated the adoption of significantly improved medium-term policy frameworks relating in particular to fiscal policy and development strategy. 


\section{Fiscal Policy}

The 2009 Budget is the first to be delivered following the Government's endorsement of a refined Medium Term Fiscal Strategy (MTFS) for the period 2008-2012. The MTFS: limits ongoing expenditure in line with 'normal revenues', defined as non-mineral revenues plus mineral revenues equal to 4\% of GDP (based on assumptions regarding long run price levels for Papua New Guinea's commodity exports); requires that additional mineral revenues above this norm be used to fund public investment projects $(70 \%)$ and repay debt $(30 \%)$; and caps the actual level of public investment expenditure sourced from additional revenue in any given year to $4 \%$ of GDP, with the remainder to be saved. Also, under the Fiscal Responsibility Act (2006), the Government can not increase the level of net public sector debt.

In his budget speech, the Minister for Treasury and Finance underscored the importance the authorities attach to this framework, both as a tool for stable and responsible macroeconomic management and as a benchmark for preserving PNG's policy credibility in the eyes of international investors and donors. The authorities will therefore give careful consideration to staff's recommendation that the Framework be fine-tuned to take explicit account of the cyclical position of the economy in determining the excess mineral revenue to be spent in any year.

Nonetheless, the existing Framework has required that the 2009 budget be framed in the context of significant declines in the level of budgeted revenues, and the absence of any 'additional revenue', as a result of sizeable falls in export prices for Papua New Guinea's major commodities. Within these constraints, the authorities have sought to allow for increased funding of key development priorities, focused on transforming the rural sector into a major driver of sustainable growth, and to support domestic demand in the face of increasing global uncertainties. In this connection, the authorities agree with staff that the key development challenge relates to unlocking the potential of the non-mineral sector.

Development spending will be guided by the priorities set out in the Medium-Term Development Strategy (MTDS), which targets an increasing share (82.7\% in 2009) of overall development funding to seven priority areas: primary and preventive health care; HIV/AIDS prevention; basic education; development-oriented adult education; transport; promotion of income-earning opportunities; and law and justice. The authorities are committed to addressing administrative and capacity constraints which have hitherto resulted in shortfalls against the MTDS's annual targets. And they consider the significant increase in funding for the District Services Improvement Program (DSIP) will help overcome endemic administrative and other capacity constraints which, in the past, have undermined community level service provision in PNG's eighty-nine districts. 
In the minerals sector, the authorities consider that the public equity investment in the proposed major LNG project, scheduled to come on line in late 2013, will ensure that the public interest is appropriately reflected in the development of a significant national resource. They fully concur with staff's observations regarding the importance of making sure that the returns to the public sector are used effectively to foster a broader-based, sustainable development.

This approach is also more broadly consistent with the authorities' adoption of a PublicPrivate Partnership (PPP) approach to shaping the public sector's role in the provision of both economic and social goods. The Asian Development Bank has been assisting the authorities in the development of an appropriate PPP framework.

With regard to the immediate future, the authorities acknowledge staff's concerns regarding the sustainability of budgeted spending, in particular regarding the implications for debt sustainability, and fully concur with the need to monitor developments carefully, and if necessary to adjust the budgetary stance at the time of the midyear review. They have expressed interest in further dialogue with Fund staff at that time on this issue.

Looking to medium term, institutional reforms have been initiated in the area of tax administration, focused on building the capacity for a more risk-based approach to auditing and enforcement activities, alongside more decentralised revenue collection arrangements involving the creation of provincial revenue offices. The authorities are exploring options for utilising technical assistance for this through PFTAC.

\section{Monetary Policy and the Exchange Rate}

The staff's recommendation regarding the stance of monetary policy and, in particular, the potential need for the Bank of PNG to be prepared to loosen quickly if leading indicators suggest domestic demand, and inflationary pressures easing more than expected, has been noted by the authorities. However, they remain inclined to caution on this front.

While there is evidence that the earlier impact of high global food and energy prices on domestic inflation eased through the latter half of 2008, domestic inflation pressures remain high. The monetary authorities considered it appropriate to progressively raise the Kina Facility Rate by 200 basis points, to $8 \%$ by December 2008, which will see real interest rates return to positive territory over the next few months in line with the forecast decline in inflation to around $6 \%$.

This represented a response to continued strong growth in bank liquidity and credit. It also reflected an awareness of the potential for the preparatory activity, and related confidence effects associated with the proposed major LNG project referred to above to underpin domestic inflationary pressures. Looking forward, the current expansionary fiscal policy 
stance, and the impact of the recently-approved increase in the minimum wage (of $170 \%$ to be phased in over 40 weeks commencing in mid-February), together with, more generally, evidence of rapid employment growth and skilled labor shortages in the formal sector, all also argue for close monitoring of inflationary pressures.

The authorities are continuing to progress arrangements to consolidate the public sector trust accounts - many of which are currently held in the private banking system - at the Bank of PNG. They agree with staff that this offers a cost-effective way of removing excess liquidity from the system.

As noted in the staff report, the real effective exchange rate appreciated over the last year, initially driven by the earlier positive terms of trade shock. More recently, the Bank of PNG has sought to lean against subsequent depreciation pressures, in order to moderate the impact on inflation and inflationary expectations. This approach reflects the importance of imports in PNG's consumer basket and doubts about the relative effectiveness of other monetary policy transmission mechanisms. The optimal pace and size of this exchange rate adjustment, however, have been the subject of debate within PNG. The authorities are very conscious of the collapse in the terms of trade and the risks that the exchange rate not adjusting would pose for competitiveness, domestic incomes and tax revenues and, ultimately, for the buildup of imbalances which would precipitate a disorderly adjustment. The points made by staff regarding the need to allow the exchange rate to adjust in response to commodity price movements, and to preserve the level of international reserves in these uncertain times, are therefore well taken and will be given careful consideration.

\section{The Financial System}

As noted by staff, PNG's financial system has been relatively unaffected by the recent global turmoil. The major banks are well-capitalised with relatively strong credit books and limited direct exposure to global markets. Similarly, the superannuation funds have continued to show positive investment returns. In both cases, this reflects to some extent the relatively undeveloped nature of PNG's financial sector (and in the case of superannuation funds, recent very strong domestic property returns). The authorities agree that this remains a longer term weakness in terms of enhancing potential growth and development. They also acknowledge the potential for the current global turmoil to negatively affect the PNG financial system indirectly through the downside risks to trade and the real sector. It is in this context that they continue to express their interest in participating in the Financial Sector Assessment Program (FSAP) later this year.

\section{Other Matters}

Implementation of the institutional changes previously suggested in addressing the need to improve the quality and timeliness of macroeconomic data has proven problematic. 
However, the authorities appreciate that this remains a very serious issue for the Fund, and for the quality of policy-making more generally, and one that must be dealt with. They will continue to engage candidly and constructively to explore practical options which can be pursued.

Finally, on this and on all other issues discussed during the consultation, my authorities would like to express their appreciation for the professionalism, technical expertise and candor that Mr. Hunt and his team brought to the table. They have indicated their agreement to publishing PNG's 2008 Article IV Report and Selected Issues papers. 